\title{
The Importance of pH: How Aquarium Water is Affecting Behavioural Responses to Drug Exposure in Larval Zebrafish.
}

\author{
Madeleine Cleal and Alistair Gibbon, Barbara. D. Fontana and Matthew. O. Parker \\ Brain and Behaviour Lab, School of Pharmacy and Biomedical Sciences, University of Portsmouth, UK.
}

\begin{abstract}
There has been rapid growth in the use of larval zebrafish as a complementary vertebrate model for drug discovery, abuse liability and pharmacological toxicology, resulting in a huge increase in zebrafish facilities worldwide. However, many research groups working with zebrafish do not typically report the $\mathrm{pH}$ of husbandry conditions in methodologies, nor are the $\mathrm{pH}$ of drug treatments reported in many research articles. This unknown factor can be a major contributor in the differential effects of drug treatments. Therefore, as a case study, we tested the impact of altering $\mathrm{pH}$ of several drugs of abuse and assessed locomotor changes associated with a single drug concentration delivered at different $\mathrm{pHs}$. We found that a change of a single $\mathrm{pH}$ unit, within the $\mathrm{pH}$ ranges commonly used in zebrafish husbandry, was enough to alter locomotor activity at a fixed drug concentration. Many pharmacological agents are dependent on environmental factors, such as $\mathrm{pH}$, to determine bioavailability. Efficaciousness for many classes of drug is dependent on their ionization state in which shifts towards uncharged species can influence the easy of a drug crossing biological membranes. Thus, we urge users to report $\mathrm{pH}$ in husbandry methods and drug treatments to improve replicability and inter-study comparisons.
\end{abstract}

\section{Introduction}

Zebrafish have been rapidly growing in popularity as a model organism (Kalueff et al., 2014; Parker et al., 2013; A M Stewart et al., 2015), lending themselves exceptionally well to studies of environmental toxicity, teratogenesis, neurotoxicity, and preclinical drug discovery (Chapela et al., 2019; Gehrig et al., 2018; Kalueff et al., 2014; Lovely et al., 2016). The high numbers of offspring, external fertilisation, transparent eggs, cost-effective maintenance and ease of genetic and pharmacological manipulation have resulted in what can now be considered as one of the most versatile and well characterised vertebrate models (Kalueff, 2017). Currently used in over 1,200 labs worldwide (zfin.org), there is growing use of zebrafish as an alternative model for both environmental and translational models. Aided by advancements in technology, zebrafish embryos and larvae have been gaining ground as a model for drug discovery due to the ease of drug administration and high-throughput whole-animal assays (Ali et al., 2011; Gehrig et al., 2018; Lieschke \& Currie, 2007; Strähle et al., 2012). Despite the success of mammalian pharmacokinetic and efficacy models, they are often expensive, time consuming, require large quantities of compounds and can be extremely invasive, particularly for dosing 
(Zon \& Peterson, 2005). Zebrafish, on the other hand, offer a cost-effective alternative which has low compound requirement and an easy method for drug delivery which is facilitated through the aqueous environment (Vaz et al., 2018; Zon \& Peterson, 2005). Thus, zebrafish are an invaluable species for screening the pre-regulatory and preclinical phases of drug discovery and pharmacological toxicology (Ali et al., 2011; Basnet et al., 2019; Chapela et al., 2019; Gehrig et al., 2018; Norton, 2013; Adam Michael Stewart et al., 2014).

Understanding the pharmacology of compounds is crucial to interpreting the interaction between chemicals and organisms. This is of particular importance when screening novel drugs for therapeutic treatments or for abuse liability, as biochemical function can be altered by temperature and $\mathrm{pH}$, critically influencing pharmacokinetics (Dowd, 2017; Mitra \& Kesisoglou, 2013; E. D. Stevens \& Balahura, 2007). Currently, 'Materials and Methods' sections in publications report general husbandry parameters, including a description of water temperature, light-dark cycles and feeding routines; however, it is not mandatory to report $\mathrm{pH}$. Subsequently, many studies do not report either environmental aquarium water (the main system water used for the majority of fish husbandry) or $\mathrm{pH}$ values of drug containing solutions. An article by Aleström, et al, outlines updated recommendations for the husbandry and care of zebrafish in line with the EU Commission Recommendation 2007/526/EC and the EU Directive 2010/63 concerning care and well-being of experimental animals (Aleström et al., 2019). This article recommends $\mathrm{pH}$ levels between 6.5-8.0. This range is inclusive of weakly acid to weakly basic conditions. Of the 154 articles examined here, only $34.4 \%$ of them reported $\mathrm{pH}$, with a range of 5.8-9.0, representing a maximal change of 2.2 units. These changes in $\mathrm{pH}$ may be accounted for by the water source for recirculating systems. This can either be from local water supplies (e.g. tap water), which is subject to effects of the local environment, such as hard versus soft water, or RO systems which rely on pre-filtration. The initial water source may influence overall $\mathrm{pH}$ levels. For example, hard water areas have increased concentrations of multivalent cations, most commonly calcium or magnesium ions, which consequently increase water $\mathrm{pH}$. Thus, with the global distribution of zebrafish facilities, fed off a vast range of water sources, it is reasonable to expect that baseline $\mathrm{pH}$ levels of aquarium water will vary from lab to lab. Although many facilities that have reported $\mathrm{pH}$ fall within the recommended $\mathrm{pH}$ levels, we demonstrate that some facilities operate outside of these parameters, thus, extending the $\mathrm{pH}$ range at which drug studies are conducted.

Here, we varied the $\mathrm{pH}$ of the test environment by a single unit, within the $\mathrm{pH}$ range recommended by Aleström, et al. We selected pH 7.0 and 8.0 to identify if this small change can influence survival or locomotor responses of larvae exposed to fixed concentrations of drug treatments. The drugs tested have been regularly used to investigate mechanisms underlying neuropsychiatric disorders, such as substance abuse, and have been selected from the same family of organic bases, to identify if $\mathrm{pH}$ is a significant factor which can alter behavioural responses to compounds that share similar chemical structures. Our findings suggest that at the concentrations selected there were no detrimental effects on survival. However, slight structural differences between compounds, resulting in variable $\mathrm{pK}_{\mathrm{a}}$ values, are significant predictors of altered organism-drug interactions that potentially result in modified locomotor responses to the same dose of drug when exposed at different $\mathrm{pH}$ conditions. Our study suggests that, when using locomotor activity as a measure of behavioural response to a drug, $\mathrm{pH}$ is a critical factor. The growing use of zebrafish as a model for screening compounds or testing novel therapeutics and many studies using locomotor activity as a behavioural end point, further supports the need to accurately report environmental conditions in which test compounds are introduced. 


\section{Materials and Methods}

\section{Systematic Review}

We carried out a systematic analysis of the reporting of $\mathrm{pH}$ in zebrafish behavioural experiments over the past 20 years. Using PubMed, we inserted the search terms "zebrafish" AND "behavio" AND "locomoto*" AND "drug". This returned 465 results, of which 154 had full free text available. Table 1 displays a summary of the data from these studies relating to reporting of $\mathrm{pH}$ (full details are included in Supplementary data_Table 1).

\section{Breeding and husbandry}

Adult, AB wild-type zebrafish (Danio rerio) were retained as breeders in the University of Portsmouth Fish Facility. Housing conditions were maintained on a re-circulating system (Aquaneering Inc., San Diego, CA, USA), with aquarium water at $\mathrm{pH} 8.4( \pm 0.4)$, temperature $25-27^{\circ} \mathrm{C}$, on a $14 \mathrm{H}: 10 \mathrm{H}$ light/dark cycle. The day prior to embryo collection male and female breeders were housed in separate tanks overnight. On the day of embryo collection, 15 mins prior to light onset, all adults were placed in a breeding tank, with males and females separated by a transparent divider. Upon light onset, the divider was removed. One hour after light onset, the adults were returned to the colony, and embryos were collected from the breeder tank. The embryos were pooled, and placed in petri dishes of aquarium water, in groups of $\sim 50$ embryos per petri dish and reared at $28{ }^{\circ} \mathrm{C}$ in aquarium water at $\mathrm{pH} 8.4$, to mimic adult conditions, in a clear incubator for three days (toxicity assessment) or seven days (behavioural assessment) on a $14 \mathrm{H}: 10 \mathrm{H}$ light/dark cycle. All studies were conducted following the guidelines of the University of Portsmouth Animal Welfare and Ethical Review Board and under licence from the UK Home Office.

\section{Pharmacological agents}

To study the effect of $\mathrm{pH}$ on different drug conditions, four commonly used drugs of abuse were selected for this study. Nicotine (Sigma-Aldrich) was administered at a concentration of 5 M (García-González et al., 2020; Petzold et al., 2009; Yoo et al., 2018), morphine sulphate (Sigma-Aldrich) was administered at $2.6 \mu \mathrm{M}$ (Lopez-Luna et al., 2017), d-amphetamine (Sigma-Aldrich) was administered at $22 \mu \mathrm{M}$ (Irons et al., 2010), and caffeine (Tocris) was administered at $200 \mu \mathrm{M}$ (Gutiérrez et al., 2020). Concentrations were based on a combination of larval and adult zebrafish studies investigating effects on locomotor activity.

\section{Toxicity assessment}

For control groups, aquarium water was buffered with citric acid to either $\mathrm{pH} 7.0$ or 8.0. For treatment groups, respective concentrations of drug were added to aquarium water and then buffered using either $\mathrm{NaHCO}_{3}$ or citric acid to bring the final $\mathrm{pH}$ to either $\mathrm{pH} 7.0$ or 8.0. The final solution $\mathrm{pH}$ values were reported at $26^{\circ} \mathrm{C}$. From the final buffered solution, $0.9 \mathrm{~mL}$ was added to each well of a 48-well plate. Individual, $3 \mathrm{dpf}$ larvae were transferred into each well for $24 \mathrm{H}$. Tail-touch-evoked motor (TEM) responses were used to assess survival at $0.5 \mathrm{H}, 1 \mathrm{H}$, 
$1.5 \mathrm{H}, 2 \mathrm{H}, 3 \mathrm{H}, 4 \mathrm{H}, 5 \mathrm{H}$ and $24 \mathrm{H}$ intervals. Plates were maintained at room temperature, $26^{\circ} \mathrm{C}$. Each drug challenge/control was conducted in separate plates with $n=8$ larvae/dose/pH. 48well plates were used due to the well sizes minimising volume of drug required per test and providing enough space for larvae to swim and for TEM to be conducted with easy. Pilot work was conducted demonstrating that TEM was a suitable and effective method for assessing survival with the drugs tested as part of this study. However, it is worth noting here that when testing drugs with analgesic properties or causing extreme hypolocomotion, TEM may be an unsuitable method for assessing survival. Under these circumstances it would be recommended that heartbeat is used as an alternative method for assessing survival. During the transfer of larvae to individual wells and the use of TEM have the potential to inflict a low level of mortality due to regular handling of larvae. To account for this, a significant effect of drug on survival was determined by treatments that caused more than $50 \%$ mortality.

\section{Larval locomotor response}

Following toxicity assessments, drugs that did not cause a significant impact on survival were used for subsequent detailed behavioural analysis. The same method of buffering drug treated, and control groups were applied as above. $7 \mathrm{dpf}$ larvae show spontaneous movement and were used to assess locomotor changes in response to drug and $\mathrm{pH}$ challenges. $7 \mathrm{dpf}$ larvae were placed in individual wells of a 48-well plate. Movement was tracked by placing plates immediately into the Zantiks MWP larval behavioural unit. Each larva was tracked individually using automated tracking software (Zantiks MWP, Cambridge, UK). Locomotor assays were run in the dark as previous studies have demonstrated that larvae move more in dark than light environments (Burgess \& Granato, 2007). Movement data were logged after $0.5 \mathrm{H}$ (acute) and $4 \mathrm{H}$ (prolonged) exposure, larvae were recorded for $30 \mathrm{mins}$. Any larvae that displayed severe immobility behaviour, defined as less than $10 \mathrm{~mm}$ travelled during each assessment, were not included in any data analyses or figures. Variance in immobility was due to individual larval differences (i.e. not overrepresented in any drug or $\mathrm{pH}$ condition), and from the total animals tested represented less than $2 \%$ of the total population.

\section{Statistical analyses}

All data were analysed using GraphPad Prism (version 8.4.2). Toxicity was assessed using Kaplan-Mayer survival curves, proportion of survival was compared to pre-drug exposure viability. Outliers from behavioural groups were identified using boxplot with Tukey analysis and excluded from subsequent analysis. Comparison of each $\mathrm{pH}$ condition was tested for normality using the Shapiro-Wilk test. Groups that were normally distributed were analysed using the unpaired $t$-test on data after outliers were excluded. Groups with non-normally distributed data were analysed using the Mann Whitney test, after the exclusion of outliers. Within each treatment group, an interaction was considered significant when $p \leq 0.05$. All data are presented as mean \pm standard error of the mean (SEM).

\section{Results}

Systematic Review 
To identify the extent to which $\mathrm{pH}$ of either husbandry or drug treatment conditions were reported in research articles relating to zebrafish behaviour, we conducted a systematic analysis of a population of published research articles in the fields of toxicology, neuroscience, drug discovery, drug testing, genetics or other. Table 1 provides a summary of our findings. We found that for each research field, $50 \%$ or less studies reported $\mathrm{pH}$, and for toxicology, neuroscience, drug discovery and drug testing, the $\mathrm{pH}$ range was greater than one unit between studies.

Table 1.

\begin{tabular}{|c|c|c|c|}
\hline Research field & Behavioural endpoint (e.g. locomotion) & $\begin{array}{l}\text { N. articles with } \mathrm{pH} \\
\text { reported/Total } \\
\text { articles }\end{array}$ & $\begin{array}{l}\text { pH value } \\
\text { (or range) }\end{array}$ \\
\hline Toxicology & $\begin{array}{l}\text { Locomotion, aggression, exploration, } \\
\text { predator interactions, social interactions, } \\
\text { shoaling }\end{array}$ & $10 / 21$ & $6.5-7.7$ \\
\hline Neuroscience & $\begin{array}{l}\text { Locomotion, anxiety, aggression, } \\
\text { exploration, escape, predator interactions, } \\
\text { social interactions, shoaling, cognition }\end{array}$ & $23 / 80$ & $6-9$ \\
\hline Drug discovery & Locomotion & $7 / 14$ & $7-9$ \\
\hline Drug testing & $\begin{array}{l}\text { Locomotion, anxiety, freezing, } \\
\text { exploration, predator interactions, } \\
\text { shoaling, stress }\end{array}$ & $9 / 26$ & $6.5-9$ \\
\hline Genetics & Locomotion, anxiety, shoaling & $3 / 9$ & 7.2-7.7 \\
\hline Other & Locomotion & $1 / 4$ & $7.9-8.3$ \\
\hline
\end{tabular}

Water challenge

The survival curve for larvae exposed to aquarium water, buffered with citric acid to either $\mathrm{pH}$ 7.0 or 8.0 , is shown below in Fig. 1A. 3 dpf larvae showed no adverse effects on survival when exposed to altered $\mathrm{pH}$ conditions for $24 \mathrm{H}$. Fig. $1 \mathrm{~B}$ shows the effect of $\mathrm{pH}$ on the total activity levels of $7 \mathrm{dpf}$ larvae during the first $0.5 \mathrm{H}$ and after a further $4 \mathrm{H}$ of exposure to their respective $\mathrm{pH}$ conditions. In the absence of drug, changes of $\pm 1.0 \mathrm{pH}$ was not sufficient to evoke changes in locomotor activity $(0.5 \mathrm{H}: t=1.719, \mathrm{df}=84, p=0.089 ; 4 \mathrm{H}: t=1.213, \mathrm{df}=84, p=0.229)$. 
A.

survival of Control pH7

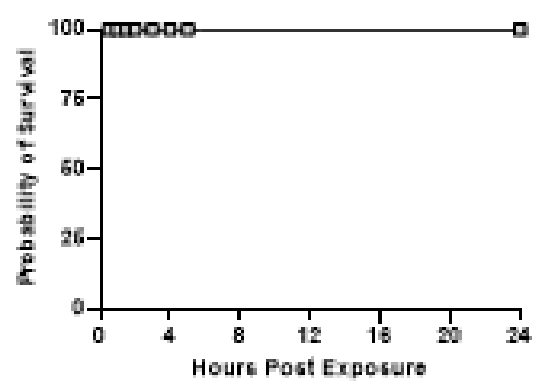

B.

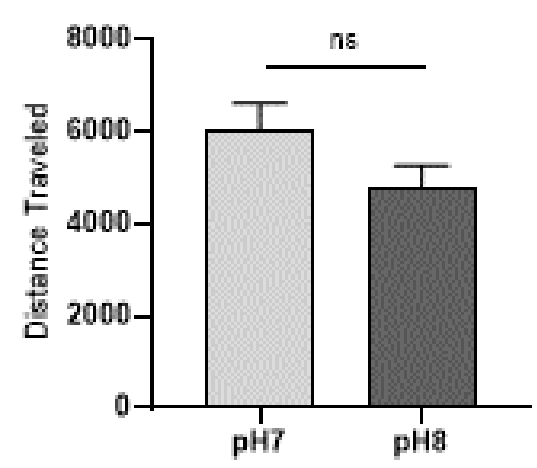

Survival of Control pH8

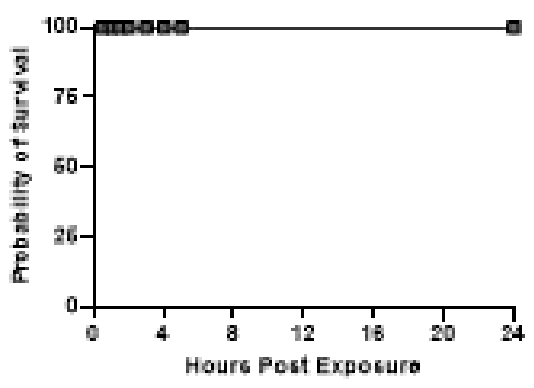

Control $4 \mathrm{H}$

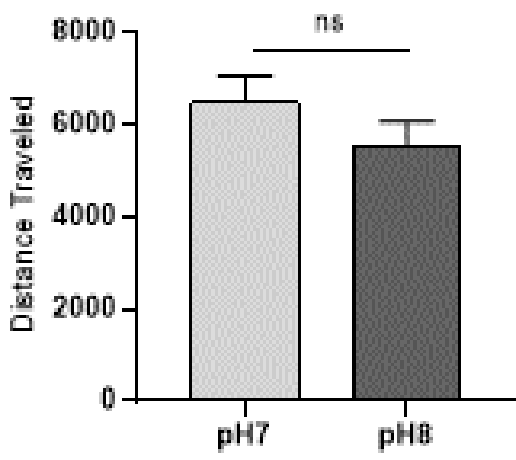

Figure 1. The effect of $\mathrm{pH}$ controlled aquarium water on $\mathbf{A}$ ) survival of $3 \mathrm{dpf}$ larvae over 24 hours, assessed using tail-touch-evoked (TEM) motor response at $0.5 \mathrm{H}, 1 \mathrm{H}, 1.5 \mathrm{H}, 2 \mathrm{H}, 3 \mathrm{H}, 4 \mathrm{H}, 5 \mathrm{H}$ and $24 \mathrm{H}$ intervals. Analysis was carried out using the Kaplan-Mayer survival curve, with proportion of survival compared to pre-drug exposure viability. Curves show $100 \%$ survival for both $\mathrm{pH}$ conditions. $\mathrm{pH} 7, \mathrm{n}=8 ; \mathrm{pH} 8, \mathrm{n}=8 \mathrm{~B}$ ) The effect of $\mathrm{pH}$ controlled aquarium water on locomotor behaviour in $7 \mathrm{dpf}$ larvae during the first $0.5 \mathrm{H}$ of exposure, and at $4 \mathrm{H}$ of exposure was analysed for outliers using boxplot with Tukey analysis. Following removal of outliers, Shapiro-Wilk normality test was conducted. Samples that were not normally distributed were analysed using Mann Whitney test. $\mathrm{pH} 7 \mathrm{n}=46 ; \mathrm{pH} 8 \mathrm{n}=46$. There was no significant difference in distance travelled between the two groups. Bars represent mean, error bars are SEM; ns - not significant.

\section{Drug challenge}

Larvae at $3 \mathrm{dpf}$ were treated with four commonly used drugs of abuse; nicotine, morphine sulphate, $d$-amphetamine and caffeine. Treatment water was buffered to either $\mathrm{pH} 7.0$ or 8.0 and the effect on survival was monitored over $24 \mathrm{H}$ of exposure (Fig. 2). Like control animals, nearly all treatment groups at both $\mathrm{pH} 7.0$ and 8.0 had $100 \%$ survival after 1 day of continuous

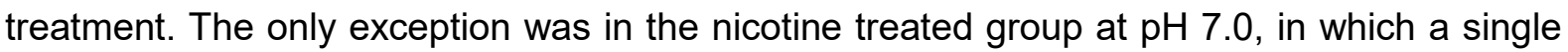
larva was reported to have died at the $24 \mathrm{H}$ time point, which, as an isolated death, it is unlikely to be the result of the treatment on survival. The survival curve analyses, demonstrated that at each of the tested concentrations, the drugs and $\mathrm{pH}$ conditions used were safe to conduct behavioural analysis on older larvae. 
Following survival curve analysis, acute $(0.5 \mathrm{H})$ and prolonged $(4 \mathrm{H})$ exposures to a single concentration of drug under two $\mathrm{pH}$ conditions were conducted using $7 \mathrm{dpf}$ larvae. Fig. $3 \mathrm{~A}$ shows the response of larvae exposed to $5 \mu \mathrm{M}$ of nicotine, which caused an increase in locomotor activity in larvae treated at $\mathrm{pH} 8.0$ compared to those treated at $\mathrm{pH} 7.0$. This increased activity level was evident after acute and prolonged exposure $(0.5 \mathrm{H}: t=2.175$, df $=$ $13, p=0.0487 ; 4 \mathrm{H}: t=2.446, \mathrm{df}=13, p=0.0294)$. Treatment with $2.6 \mu \mathrm{M}$ of morphine sulphate, showed no locomotor difference after an acute exposure $(0.5 \mathrm{H}: t=0.314 \mathrm{df}=14, p$ $=0.758$ ). However, differences in activity levels were evident after prolonged treatment, resulting in a significant increase in the distance travelled by larvae in the group buffered to $\mathrm{pH} 8.0(4 \mathrm{H}: t=2.990, \mathrm{df}=14, p=0.0098)$ (Fig. 3B). Larvae treated with $22 \mu \mathrm{M}$ of $d-$ amphetamine showed no differences between $\mathrm{pH}$ groups after acute exposure $(0.5 \mathrm{H}: t=$ 1.984 , df $=13, p=0.0688$ ). However, after prolonged exposure there was a significant effect of $\mathrm{pH} 8.0$ causing a decrease in locomotor activity compared to larvae treated at $\mathrm{pH} 7.0(4 \mathrm{H}$ : $t=2.883, \mathrm{df}=13, p=0.0128$ ) (Fig. $3 \mathrm{C}$ ). Caffeine caused no detectable differences between $\mathrm{pH}$ groups either at the acute or prolonged treatment stages $(0.5 \mathrm{H}: t=1.183, \mathrm{df}=13, p=$ $0.258 ; 4 \mathrm{H}: t=0.835, \mathrm{df}=14, p=0.418$ ) (Fig. 3D). 
A.
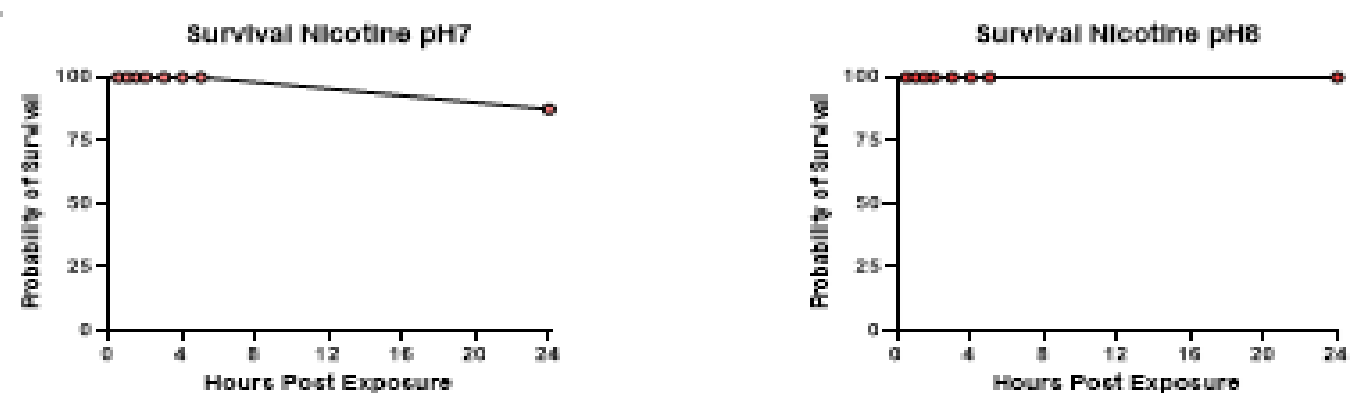

B.
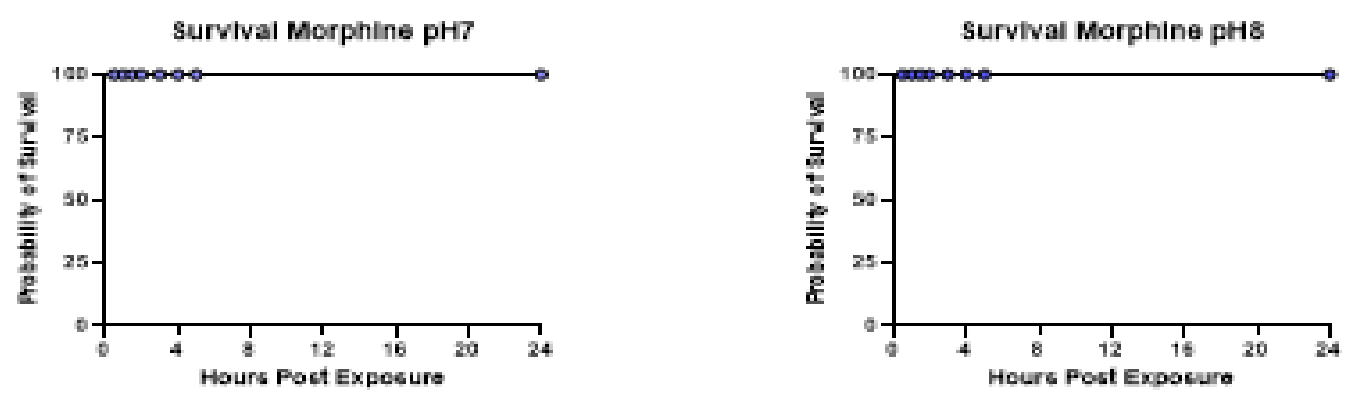

C.
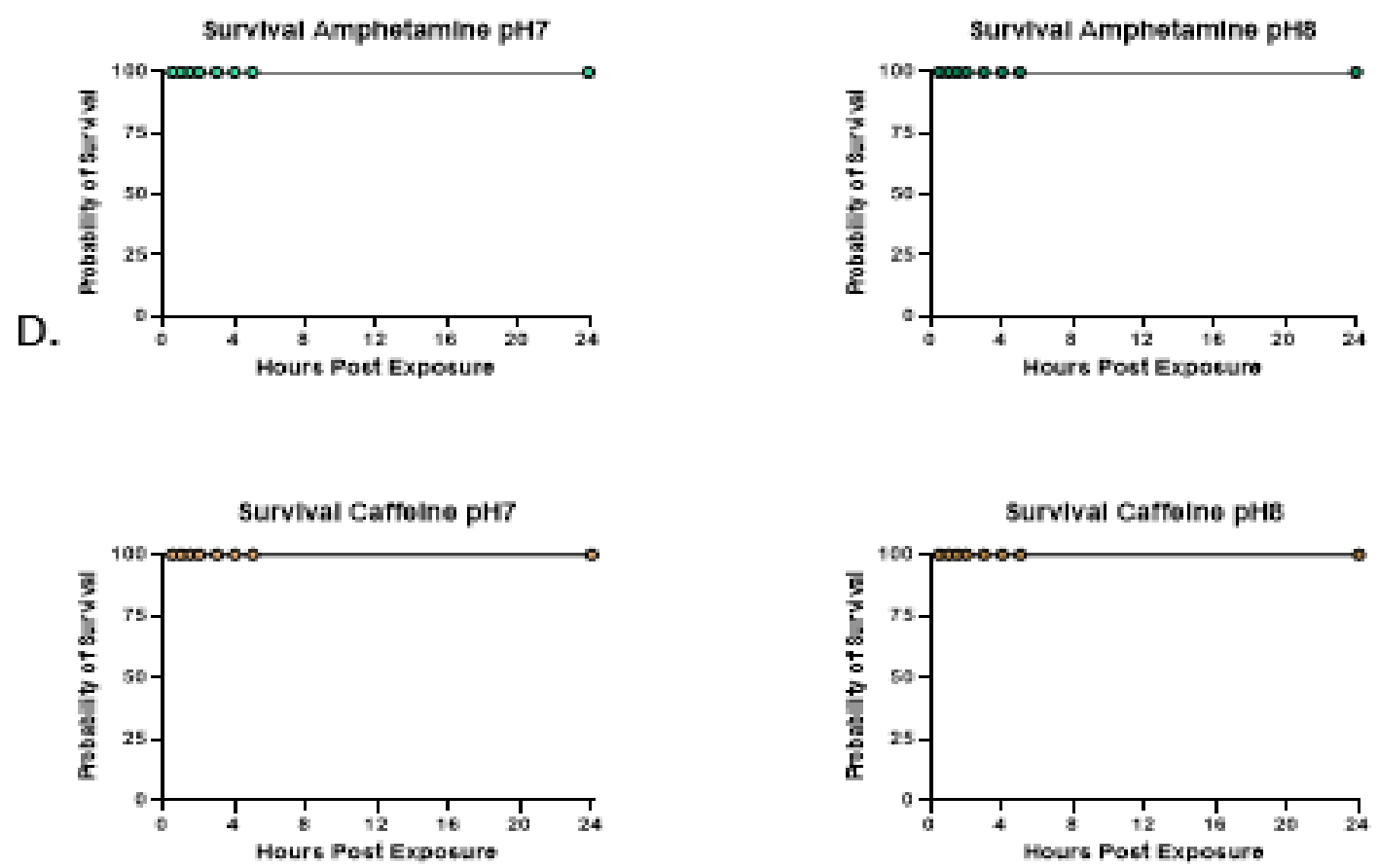

Figure 2. The effect of $\mathrm{pH}$ controlled drug treatment on the survival of $3 \mathrm{dpf}$ larvae over 24 hours, assessed using tail flick at $0.5 \mathrm{H}, 1 \mathrm{H}, 1.5 \mathrm{H}, 2 \mathrm{H}, 3 \mathrm{H}, 4 \mathrm{H}, 5 \mathrm{H}$ and $24 \mathrm{H}$ intervals for A) $5 \mu \mathrm{M}$ nicotine, B) $2.6 \mu \mathrm{M}$ morphine sulphate, C) $22 \mu \mathrm{M}$ of d-amphetamine and D) $200 \mu \mathrm{M}$ caffeine. Analysis was carried out using the KaplanMayer survival curve, with proportion of survival compared to pre-drug exposure viability. Survival curves show $100 \%$ survival for both $\mathrm{pH}$ conditions for all drug exposures, except $\mathrm{pH} 7$ nicotine, which reported a single death. $\mathrm{pH} 7 \mathrm{n}=8 ; \mathrm{pH} 8 \mathrm{n}=8$ for each drug condition. 
A.

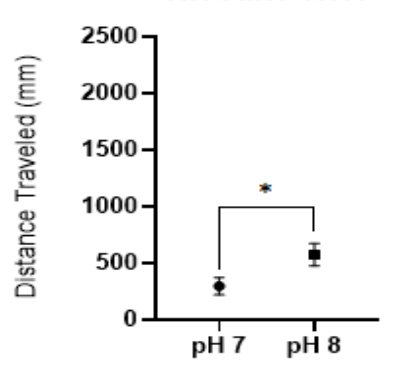

B.

Morphine $\mathbf{0 . 5 \mathrm { H }}$

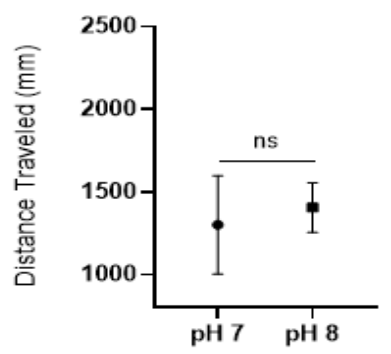

C.

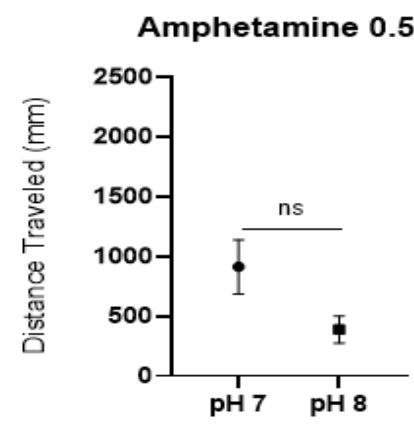

D.

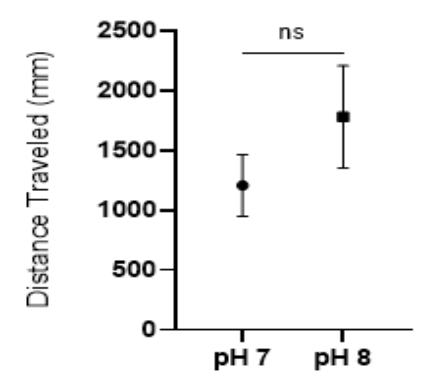

Nicotine $4 \mathrm{H}$
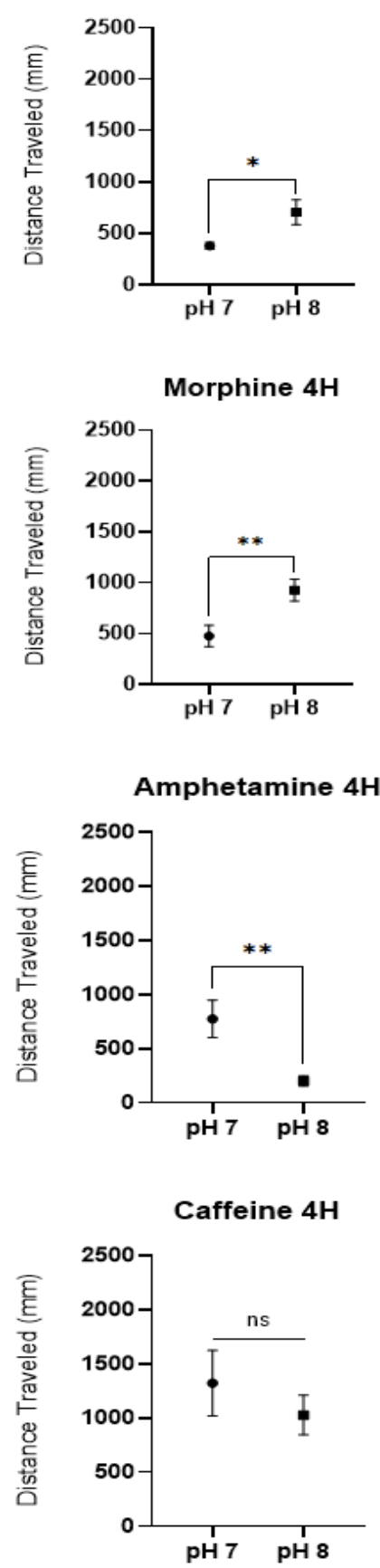

Figure 3. The effect of $\mathrm{pH}$ controlled drug treatments on locomotor activity of $7 \mathrm{dpf}$ larvae assessed using automated tracking software for the first $0.5 \mathrm{H}$ of exposure (acute) and after $4 \mathrm{H}$ of exposure (prolonged). Treatments were buffered to either $\mathrm{pH} 7.0$ or $\mathrm{pH} 8.0$ ( \pm 0.1 ) using citric acid. A) $5 \mu \mathrm{M}$ nicotine, B) $2.6 \mu \mathrm{M}$ morphine sulphate, C) $22 \mu \mathrm{M}$ of d-amphetamine and D) $200 \mu \mathrm{M}$ caffeine. Analysis for outliers was carried out using boxplot with Tukey analysis. Following removal of outliers, Shapiro-Wilk normality test was conducted. Samples that were normally distributed were analysed by unpaired t-test, not normally distributed samples were analysed using Mann-Whitney test. Nicotine, $0.5 \mathrm{H}: \mathrm{pH} 7 \mathrm{n}=7, \mathrm{pH} 8 \mathrm{n}=8,4 \mathrm{H}: \mathrm{pH} 7 \mathrm{n}=7, \mathrm{pH} 8 \mathrm{n}=8$. Morphine, $0.5 \mathrm{H}$ : $\mathrm{pH} 7 \mathrm{n}=8, \mathrm{pH} 8 \mathrm{n}=8,4 \mathrm{H}: \mathrm{pH} 7 \mathrm{n}=8, \mathrm{pH} 8 \mathrm{n}=8$. Amphetamine, $0.5 \mathrm{H}: \mathrm{pH} 7 \mathrm{n}=8, \mathrm{pH} 8 \mathrm{n}=7,4 \mathrm{H}: \mathrm{pH} 7$ $\mathrm{n}=8, \mathrm{pH} 8 \mathrm{n}=7$. Caffeine, $0.5 \mathrm{H}: \mathrm{pH} 7 \mathrm{n}=8, \mathrm{pH} 8 \mathrm{n}=8,4 \mathrm{H}: \mathrm{pH} 7 \mathrm{n}=8, \mathrm{pH} 8 \mathrm{n}=8$. Bars represent mean, error bars are SEM; ns - not significant, ${ }^{*} p<0.05,{ }^{*} p<0.01$. 


\section{Discussion}

The aim of this study was to assess if a change of environmental $\mathrm{pH}$ was substantive enough to cause a change in behavioural activity when larvae were exposed to the same concentration of drug at different pH's. We found that a change in $\mathrm{pH}$ of \pm 1.0 unit significantly impacted locomotor activity of larvae for three of the four test drugs. Nicotine was found to have a $\mathrm{pH}-$ dependent effect that immediately impacted locomotor activity. This effect was sustained over both acute and prolonged exposure. Morphine and $d$-amphetamine both showed altered locomotor responses based on $\mathrm{pH}$, but only after prolonged exposure. Caffeine was the only drug tested that did not cause different activity levels between $\mathrm{pH}$ groups. Our findings suggest that the chemical composition of a drug can be a strong determinant in the effect of $\mathrm{pH}$ on behavioural response, potentially due to altered bioavailability. Our results thus highlight the differential effects that small changes in $\mathrm{pH}$ can have on behavioural output in response to drug exposure.

Zebrafish have been found to live in bodies of water with $\mathrm{pH}$ varying from 6 to 10 , demonstrating suitability to a wide range of environments (Aleström et al., 2019; Arunachalam et al., 2013). However, in laboratory settings, the aim has been to provide stable husbandry conditions, and thus zebrafish housing systems have been recommended at $\mathrm{pH}$ 6.5-8.0 (Aleström et al., 2019). Analysis of 154 studies assessing effects of drugs on zebrafish behaviour showed the most widely used $\mathrm{pH}$ levels fell between $\mathrm{pH} 7.0-8.0$, found in $77 \%$ of studies reporting $\mathrm{pH}$ (Supplementary data_Table 1). We assessed if aquarium water buffered to either $\mathrm{pH} 7.0$ or 8.0 , reducing our normal aquarium water levels by 1.4 or 0.4 respectively, caused differences in toxicity to $3 \mathrm{dpf}$ larvae or baseline locomotor activity of 7 dpf larvae. We found that there was no difference in the survival rate over $24 \mathrm{H}$, in which both $\mathrm{pH}$ conditions had $100 \%$ survival. There was also no evidence of $\mathrm{pH}$ related changes in locomotion, as both groups showed similar distances moved after acute and prolonged exposure to $\mathrm{pH}$ altered aquarium water. Similar to control groups, toxicity studies of test drugs at $\mathrm{pH} 7.0$ and 8.0 , revealed that over $24 \mathrm{H}$ of exposure, the selected concentrations did not cause any toxic effects, thus resulting in $100 \%$ survival in all conditions. However, behavioural assessment of locomotion at $7 \mathrm{dpf}$ revealed significant $\mathrm{pH}$-dependent differences in response to a fixed dose of drug with variable $\mathrm{pH}$ conditions.

Here, we demonstrated that within the first $0.5 \mathrm{H}$ of exposure of $7 \mathrm{dpf}$ larvae to $5 \mu \mathrm{M}$ nicotine, there was an immediate difference in the locomotor activity of larvae at $\mathrm{pH} 7.0$ compared to those treated at $\mathrm{pH}$ 8.0. Nicotine is a weakly basic drug and can exist in three forms in aqueous solution: the univalent (pyrrolidinium) cation, divalent cation and the unionized 'free base' (Barlow \& Hamilton, 1962). At physiological pH (ca. 7.4), 69\% of nicotine is present in the ionized form (predominantly the univalent cation) (Pogocki et al., 2007). The rest remains unionized (uncharged) and it is in this form that molecules are easily absorbed, as the free base can readily pass across biological membranes (Benowitz et al., 2009; Pogocki et al., 2007). Absorption in this state is rapid, and in conjunction with moderate hydrophobicity and low polarity (due to the presence of the pyridine and pyrrolidine rings) nicotine can easily cross the blood-brain barrier to access the brain (W. H. Oldendorf, 1974; William H. Oldendorf et al., 1993; Spector \& Goldberg, 1982; Tega et al., 2018). When nicotine is present in aqueous solution at $25{ }^{\circ} \mathrm{C}$, it has two $\mathrm{pK}_{\mathrm{a}}$ values; 8.02 and 3.12 . If the environmental $\mathrm{pH}$, that the drug is dissolved in, is equal to the $\mathrm{pK}_{\mathrm{a}}$ value, then there are equal quantities of drug in the ionized 
and nonionized forms (50:50) (Dowd, 2017). Therefore, when nicotine is solubilized in $\mathrm{pH} 8.0$, equal to the $\mathrm{pk}_{\mathrm{a}}$ value, $\sim 50 \%$ of the nicotine must be in the unionized state. Many studies have reported that at physiological $\mathrm{pH}, 31 \%$ of nicotine is the free base species. Therefore, at $\mathrm{pH}$ 7.0 , it would be expected that an even higher degree of ionization would occur, thus reducing the total amount of free base available to less than $30 \%$ (Pogocki et al., 2007). This represents a difference of greater than $20 \%$ nonionized, biologically available nicotine between $\mathrm{pH} 7.0$ and 8.0. Zebrafish larvae treated at $\mathrm{pH} 8.0$ had a mean of $572.4 \mathrm{~mm}$ travelled during acute exposure to nicotine, while larvae treated at pH 7.0 on average only travelled $294.2 \mathrm{~mm}$, almost half the distance travelled by the $\mathrm{pH} 8.0$ treated group. These findings of increasing locomotor activity with increasing nicotine concentration is supported by a previous study from Petzold, et al, investigating the effect of nicotine concentration on zebrafish larvae locomotion. They demonstrated that increasing concentrations of nicotine from $2.5 \mu \mathrm{M}$ to $50 \mu \mathrm{M}$ resulted in increases in movement (Petzold et al., 2009). Therefore, it is likely that hyperlocomotion of larvae treated at $\mathrm{pH} 8.0$ are the result of increased nicotine availability (effectively increasing brain concentration of nicotine) by altering the amount of unionized nicotine in solution.

Morphine and $d$-amphetamine have similar chemical properties to nicotine. In aqueous solution, morphine can be found in three forms: two ionized forms (one with a charge on the nitrogen atom and the other lacking a proton on the phenolic hydroxyl group at carbon 3) and an uncharged, free base (E. D. Stevens \& Balahura, 2007). D-amphetamine is only found in two forms: an ionized cation and the free base (Pubchem). Morphine, like nicotine, has two equilibrium constants $\left(\mathrm{pK}_{\mathrm{a}}\right.$ ) of 8.00 and 9.75 , whilst $d$-amphetamine has one of 9.9 at $25^{\circ} \mathrm{C}$ (Heal et al., 2013). Due to the weakly basic properties of both drugs, like nicotine, there is consequently more of the drug present in the lipid soluble, free base form when in more alkali $\mathrm{pH}$ conditions, thus increasing absorption and brain concentration of drug (Dowd, 2017). Acute exposure to both morphine and $d$-amphetamine, had no $\mathrm{pH}$-induced differences in motor activity. However, the effect of altered $\mathrm{pH}$ condition became evident after prolonged exposure (4H of treatment), which caused significant differences in the distances travelled in the drug treated groups at $\mathrm{pH} 7.0$ compared to $\mathrm{pH}$ 8.0. Morphine treated larvae behaved similarly to nicotine treated larvae, both groups demonstrating hyperlocomotion in $\mathrm{pH} 8.0$ compared to $\mathrm{pH}$ 7.0. Almost identical $\mathrm{pK}_{\mathrm{a}}$ values of nicotine (8.02) and morphine (8.00) may be a principle factor in the similar behavioural responses of increased locomotion with increasing brain concentrations of available drug (Barlow \& Hamilton, 1962; E. D. Stevens \& Balahura, 2007; Tomar, Scott \& Henningfield, Jack, 1997).

The percentage of the ionized versus nonionized form depends on the number of $\mathrm{pH}$ units above or below the $\mathrm{pK}_{\mathrm{a}}$ (Bhagavan, 2002). As morphine and nicotine have $\mathrm{pK}_{\mathrm{a}}$ values of $\sim 8.0( \pm 0.2)$, the degree of ionization at $\mathrm{pH} 7.0$ would be expected to be similar, $\sim 20 \%$ lower than at $\mathrm{pH}$ 8.0. Therefore, the increase in bioavailability of morphine would be expected to cause a similar response to nicotine based on the same degree of ionization at their respective pHs. $D$-amphetamine, however, caused the opposite effect in the prolonged treated group, resulting in hypolocomotion of larvae treated at $\mathrm{pH} 8.0$ compared to $\mathrm{pH}$ 7.0. Previous studies of zebrafish larvae exposed to $d$-amphetamine reported an "inverted U" dose-response in locomotor activity dependent on drug concentration (Irons et al., 2010). Irons, et al, reported that low doses, up to $2.2 \mu \mathrm{M}$ caused hyperlocomotion, whilst doses from $6.6 \mu \mathrm{M}$ began to cause increased hypolocomotion, with the maximal dose tested $(20 \mu \mathrm{M})$ having the greatest effect on hypoactivity, similarly found here with a dose of $22 \mu \mathrm{M}$ (Irons et al., 2010). Thus, in line with this study, we found that the $\mathrm{pH}$ with the highest level of $d$-amphetamine in the free base form, $\mathrm{pH} 8.0$, caused the greatest reduction in distance moved in $7 \mathrm{dpf}$ larvae. 
Differences in the onset of $\mathrm{pH}$-dependent locomotor changes found between amphetamine and morphine compared to nicotine, could be the result of relative absorption times. Oral administration of nicotine has been reported to have an almost immediate effect, whilst previous studies using amphetamine have reported that peak responses from oral administration was $1-3 \mathrm{H}$ post exposure (Schepers et al., 2003). It is therefore possible, that the lack of effect seen in the acute dose of morphine and $d$-amphetamine was a result of incomplete or limited absorption at that stage, thus only after sufficient exposure time is there an effect of the drug on behavioural output. These three drugs each have similar chemical compositions which include an alkaloid amine group which is deprotonated forming the free base (nonionized) species (Völgyi et al., 2010). The weak alkalinity and the similar $\mathrm{pK}_{\mathrm{a}}$ values result in drugs that are readily absorbed under more basic conditions (Bhagavan, 2002).

The only drug tested that did not follow this trend of $\mathrm{pH}$-dependent locomotor activity was caffeine. Although, like the other test drugs, caffeine also has an alkaloid amine group and is weakly basic, it has two $\mathrm{pK}_{\mathrm{a}}$ values of 0.7 and 14.0. Subsequently, caffeine is found in a neutral state at pH 5-9 (National Center for Biotechnology Information, 2020; Švorc, 2013). Consequently, as the test environments both fall within this range, there is no difference in the percentage of ionized/nonionized caffeine in solution, thus behavioural changes as a result of exposure to $200 \mu \mathrm{M}$ caffeine, would be expected to affect larvae in both $\mathrm{pH}$ groups equally. Therefore, as expected, there were no detectable changes in locomotor activity between $\mathrm{pH}$ groups treated with caffeine after acute or prolonged exposure. Previous studies investigating the effect of different concentrations of caffeine on locomotion have also reported no difference between doses (Gutiérrez et al., 2020).

To our knowledge this is the first systematic investigation of the effects of varying $\mathrm{pH}$ conditions on the biological activity of drugs, using locomotion as a behavioural endpoint. The aim of this study was to highlight the importance of reporting this environmental condition, demonstrating that changes of a single $\mathrm{pH}$ unit can be sufficient to influence locomotor responses to a fixed concentration of drug. We appreciate that the controlling factor of $\mathrm{pH}$ conditions in aquatic facilities is the water source used to feed the system. Changing this system is impractical and in many cases can be cost prohibitive. We are therefore not suggesting that facilities attempted to alter husbandry conditions to fit within the range recommended by (Aleström et al., 2019). Zebrafish can be found living under a broad range of conditions in the wild, and as part of the literature review, we found no study that conducted work outside of the natural range that zebrafish have been found to live in. Although it has not been systematically assessed how long-term exposure to varying $\mathrm{pH}$ conditions affects behaviour in a laboratory setting, it is our belief that as long as fish are kept within the natural environmental range this should be acceptable. However, future investigations would be of great use as a resource to the zebrafish community. Based on our findings here, we suggest carrying out drug treatments at a similar $\mathrm{pH}$ to the housing conditions to prevent any shock responses from rapidly changing environmental conditions, which could require additional habituation periods or cause behavioural artefacts. Instead we propose that when carrying out drug treatments the $\mathrm{pH}$ value is taken into consideration as part of the experimental design. To prevent the addition of drug induced fluctuations to test conditions, we recommend either neutralising or matching drug solutions to aquarium water $\mathrm{pH}$. Reporting of $\mathrm{pH}$ conditions and awareness of $\mathrm{pKa}$ values of test drugs when designing experiments and drawing conclusions will greatly aid in improving replicability between laboratories and provide a potential mechanism for interlab differences when testing the same drug at what appears to be the same concentration. Our understanding of how environmental conditions can influence 
experimental design, particularly in light of toxicology studies, drug discovery and drug testing using aquatic organisms is in its infancy. Future work investigating the effects of altered environmental conditions in the presence of a drug on behaviour and bioavailability and how drug $\mathrm{x} \mathrm{pH}$ interactions apply to adult zebrafish behaviour would provide invaluable information for those testing zebrafish with drugs or toxins. Understanding how environmental conditions can influence experiments may prove a valuable tool in optimising zebrafish as a model organism.

\section{Conclusion}

With the increasing use of high-throughput behavioural screening of zebrafish larvae for assessing pharmacological agents, the need to improve inter-lab reproducibility is of critical importance. This study demonstrates that four drugs from the same family of organic bases can all exert different effects on locomotor responses by altering environmental conditions by a single $\mathrm{pH}$ unit. We have reported that even small changes can cause significant effects and could result in substantial differences in the way larvae, and potentially adult zebrafish respond to drug exposure. It is currently not mandatory to report the $\mathrm{pH}$ of aquarium water or of drug treated water in which fish are immersed. We demonstrated that from a sample of studies less than $35 \%$ reported $\mathrm{pH}$. We therefore propose that the zebrafish community start to report $\mathrm{pH}$ values of drug conditions and general husbandry so that results can be more accurately replicated and compared between studies.

\section{Reference}

Afrikanova, T., Serruys, A.-S. K., Buenafe, O. E. M., Clinckers, R., Smolders, I., de Witte, P. A. M., Crawford, A. D., \& Esguerra, C. V. (2013). Validation of the zebrafish pentylenetetrazol seizure model: locomotor versus electrographic responses to antiepileptic drugs. PloS One, 8(1), e54166. https://doi.org/10.1371/journal.pone.0054166

Aleström, P., D’Angelo, L., Midtlyng, P. J., Schorderet, D. F., Schulte-Merker, S., Sohm, F., \& Warner, S. (2019). Zebrafish: Housing and husbandry recommendations. Laboratory Animals, 002367721986903. https://doi.org/10.1177/0023677219869037

Ali, S., Champagne, D. L., Spaink, H. P., \& Richardson, M. K. (2011). Zebrafish embryos and larvae: A new generation of disease models and drug screens. In Birth Defects Research Part C - Embryo Today: Reviews (Vol. 93, Issue 2, pp. 115-133). https://doi.org/10.1002/bdrc.20206

Altenhofen, S., Nabinger, D. D., Wiprich, M. T., Pereira, T. C. B., Bogo, M. R., \& Bonan, C. D. (2017). Tebuconazole alters morphological, behavioral and neurochemical parameters in larvae and adult zebrafish (Danio rerio). Chemosphere, 180, 483-490. https://doi.org/10.1016/j.chemosphere.2017.04.029

Anichtchik, O. V, Kaslin, J., Peitsaro, N., Scheinin, M., \& Panula, P. (2004). Neurochemical and behavioural changes in zebrafish Danio rerio after systemic administration of 6hydroxydopamine and 1-methyl-4-phenyl-1,2,3,6-tetrahydropyridine. Journal of Neurochemistry, 88(2), 443-453. https://doi.org/10.1111/j.1471-4159.2004.02190.x

Annunziato, K. M., Jantzen, C. E., Gronske, M. C., \& Cooper, K. R. (2019). Subtle morphometric, behavioral and gene expression effects in larval zebrafish exposed to 
PFHxA, PFHxS and 6:2 FTOH. Aquatic Toxicology (Amsterdam, Netherlands), 208, 126-137. https://doi.org/10.1016/j.aquatox.2019.01.009

Arunachalam, M., Raja, M., Vijayakumar, C., Malaiammal, P., \& Mayden, R. L. (2013). Natural history of zebrafish (Danio rerio) in India. Zebrafish, 10(1), 1-14. https://doi.org/10.1089/zeb.2012.0803

Baiamonte, M., Brennan, C. H., \& Vinson, G. P. (2015). Sustained action of developmental ethanol exposure on the cortisol response to stress in zebrafish larvae and adults. PLoS ONE. https://doi.org/10.1371/journal.pone.0124488

Baiamonte, M., Parker, M. O., Vinson, G. P., \& Brennan, C. H. (2016). Sustained Effects of Developmental Exposure to Ethanol on Zebrafish Anxiety-Like Behaviour. PLoS ONE. https://doi.org/10.1371/journal.pone.0148425

Bailey, J. M., Oliveri, A. N., Karbhari, N., Brooks, R. A. J., De La Rocha, A. J., Janardhan, S., \& Levin, E. D. (2016). Persistent behavioral effects following early life exposure to retinoic acid or valproic acid in zebrafish. Neurotoxicology, 52, 23-33. https://doi.org/10.1016/j.neuro.2015.10.001

Baldissarelli, L. A., Capiotti, K. M., Bogo, M. R., Ghisleni, G., \& Bonan, C. D. (2012). Arsenic alters behavioral parameters and brain ectonucleotidases activities in zebrafish (Danio rerio). Comparative Biochemistry and Physiology. Toxicology \& Pharmacology: CBP, 155(4), 566-572. https://doi.org/10.1016/j.cbpc.2012.01.006

Baraban, S. C., Dinday, M. T., Castro, P. A., Chege, S., Guyenet, S., \& Taylor, M. R. (2007). A large-scale mutagenesis screen to identify seizure-resistant zebrafish. Epilepsia, 48(6), 1151-1157. https://doi.org/10.1111/j.1528-1167.2007.01075.x

Barlow, R. ., \& Hamilton, J. T. (1962). EFFECTS OF pH ON THE ACTIVITY OF NICOTINE AND NICOTINE MONOMETHIODIDE ON THE RAT DIAPHRAGM PREPARATION. British Journal of Pharmacology and Chemotherapy, 18(3), 543-549. https://doi.org/10.1111/j.1476-5381.1962.tb01173.x

Baronio, D., Puttonen, H. A. J., Sundvik, M., Semenova, S., Lehtonen, E., \& Panula, P. (2018). Embryonic exposure to valproic acid affects the histaminergic system and the social behaviour of adult zebrafish (Danio rerio). British Journal of Pharmacology, 175(5), 797-809. https://doi.org/10.1111/bph.14124

Barros, T. P., Alderton, W. K., Reynolds, H. M., Roach, A. G., \& Berghmans, S. (2008). Zebrafish: an emerging technology for in vivo pharmacological assessment to identify potential safety liabilities in early drug discovery. British Journal of Pharmacology, 154(7), 1400-1413. https://doi.org/10.1038/bjp.2008.249

Basnet, R. M., Guarienti, M., \& Memo, M. (2017). Zebrafish Embryo as an In Vivo Model for Behavioral and Pharmacological Characterization of Methylxanthine Drugs.

International Journal of Molecular Sciences, 18(3). https://doi.org/10.3390/ijms18030596

Basnet, R. M., Zizioli, D., Taweedet, S., Finazzi, D., \& Memo, M. (2019). Zebrafish larvae as a behavioral model in neuropharmacology. In Biomedicines (Vol. 7, Issue 1). MDPI AG. https://doi.org/10.3390/BIOMEDICINES7010023

Batista, F. L. A., Lima, L. M. G., Abrante, I. A., de Araújo, J. I. F., Batista, F. L. A., Abrante, I. A., Magalhães, E. A., de Lima, D. R., Lima, M. da C. L., do Prado, B. S., Moura, L. F. W. G., Guedes, M. I. F., Ferreira, M. K. A., de Menezes, J. E. S. A., Santos, S. A. A. R., Mendes, F. R. S., Moreira, R. A., Monteiro-Moreira, A. C. O., Campos, A. R., \& Magalhães, F. E. A. (2018). Antinociceptive activity of ethanolic extract of Azadirachta indica A. Juss (Neem, Meliaceae) fruit through opioid, glutamatergic and acid-sensitive 
ion pathways in adult zebrafish (Danio rerio). Biomedicine \& Pharmacotherapy $=$ Biomedecine \& Pharmacotherapie, 108, 408-416.

https://doi.org/10.1016/j.biopha.2018.08.160

Bencan, Z., \& Levin, E. D. (2008). The role of alpha7 and alpha4beta2 nicotinic receptors in the nicotine-induced anxiolytic effect in zebrafish. Physiology \& Behavior, 95(3), 408412. https://doi.org/10.1016/j.physbeh.2008.07.009

Benedetti, L., Ghilardi, A., Rottoli, E., De Maglie, M., Prosperi, L., Perego, C., Baruscotti, M., Bucchi, A., Del Giacco, L., \& Francolini, M. (2016). INaP selective inhibition reverts precocious inter- and motorneurons hyperexcitability in the Sod1-G93R zebrafish ALS model. Scientific Reports, 6, 24515. https://doi.org/10.1038/srep24515

Benowitz, N. L., Hukkanen, J., Jacob, P., \& III. (2009). Nicotine chemistry, metabolism, kinetics and biomarkers. Handbook of Experimental Pharmacology, 192, 29-60. https://doi.org/10.1007/978-3-540-69248-5_2

Bhagavan, N. V. (2002). Water, Acids, Bases, and Buffers. In Medical Biochemistry (pp. 116). Academic Press. https://doi.org/10.1016/b978-012095440-7/50003-2

Boehmler, W., Carr, T., Thisse, C., Thisse, B., Canfield, V. A., \& Levenson, R. (2007). D4 Dopamine receptor genes of zebrafish and effects of the antipsychotic clozapine on larval swimming behaviour. Genes, Brain and Behavior, 6(2), 155-166. https://doi.org/10.1111/j.1601-183X.2006.00243.x

Bortolotto, J. W., de Melo, G. M., Cognato, G. de P., Vianna, M. R. M., \& Bonan, C. D. (2015). Modulation of adenosine signaling prevents scopolamine-induced cognitive impairment in zebrafish. Neurobiology of Learning and Memory, 118, 113-119. https://doi.org/10.1016/J.NLM.2014.11.016

Braga, M. M., Silva, E. S., Moraes, T. B., Schirmbeck, G. H., Rico, E. P., Pinto, C. B., Rosemberg, D. B., Dutra-Filho, C. S., Dias, R. D., Oliveira, D. L., T Rocha, J. B., \& Souza, D. O. (2016). Brain zinc chelation by diethyldithiocarbamate increased the behavioral and mitochondrial damages in zebrafish subjected to hypoxia. Scientific Reports, 6, 20279. https://doi.org/10.1038/srep20279

Bridi, D., Altenhofen, S., Gonzalez, J. B., Reolon, G. K., \& Bonan, C. D. (2017). Glyphosate and Roundup $\left({ }^{\circledR}\right)$ alter morphology and behavior in zebrafish. Toxicology, 392, 32-39. https://doi.org/10.1016/j.tox.2017.10.007

Brock, A. J., Goody, S. M. G., Mead, A. N., Sudwarts, A., Parker, M. O., \& Brennan, C. H. (2017). Assessing the value of the zebrafish conditioned place preference model for predicting human abuse potential. Journal of Pharmacology and Experimental Therapeutics, 363(1), jpet.117.242628. https://doi.org/10.1124/jpet.117.242628

Brun, N. R., van Hage, P., Hunting, E. R., Haramis, A.-P. G., Vink, S. C., Vijver, M. G., Schaaf, M. J. M., \& Tudorache, C. (2019). Polystyrene nanoplastics disrupt glucose metabolism and cortisol levels with a possible link to behavioural changes in larval zebrafish. Communications Biology, 2, 382. https://doi.org/10.1038/s42003-019-0629-6

Brustein, E., \& Drapeau, P. (2005). Serotoninergic modulation of chloride homeostasis during maturation of the locomotor network in zebrafish. The Journal of Neuroscience: The Official Journal of the Society for Neuroscience, 25(46), 10607-10616. https://doi.org/10.1523/JNEUROSCI.2017-05.2005

Bugel, S. M., \& Tanguay, R. L. (2018). Multidimensional chemobehavior analysis of flavonoids and neuroactive compounds in zebrafish. Toxicology and Applied Pharmacology, 344, 23-34. https://doi.org/10.1016/j.taap.2018.02.019 
Burgess, H. A., \& Granato, M. (2007). Modulation of locomotor activity in larval zebrafish during light adaptation. Journal of Experimental Biology, 210(14), 2526-2539. https://doi.org/10.1242/jeb.003939

Cachat, J., Stewart, A., Utterback, E., Hart, P., Gaikwad, S., Wong, K., Kyzar, E., Wu, N., \& Kalueff, A. V. (2011). Three-dimensional neurophenotyping of adult zebrafish behavior. PloS One, 6(3), e17597. https://doi.org/10.1371/journal.pone.0017597

Carvan, M. J. 3rd, Kalluvila, T. A., Klingler, R. H., Larson, J. K., Pickens, M., MoraZamorano, F. X., Connaughton, V. P., Sadler-Riggleman, I., Beck, D., \& Skinner, M. K. (2017). Mercury-induced epigenetic transgenerational inheritance of abnormal neurobehavior is correlated with sperm epimutations in zebrafish. PloS One, 12(5), e0176155. https://doi.org/10.1371/journal.pone.0176155

Chapela, D., Sousa, S., Martins, I., Cristóvão, A. M., Pinto, P., Corte-Real, S., \& Saúde, L. (2019). A zebrafish drug screening platform boosts the discovery of novel therapeutics for spinal cord injury in mammals. Scientific Reports, 9(1), 1-12.

https://doi.org/10.1038/s41598-019-47006-w

Chen, P.-Y., Tu, H.-C., Schirch, V., Safo, M. K., \& Fu, T.-F. (2019). Pyridoxamine Supplementation Effectively Reverses the Abnormal Phenotypes of Zebrafish Larvae With PNPO Deficiency. Frontiers in Pharmacology, 10, 1086. https://doi.org/10.3389/fphar.2019.01086

Chhabria, K., Vouros, A., Gray, C., MacDonald, R. B., Jiang, Z., Wilkinson, R. N., Plant, K., Vasilaki, E., Howarth, C., \& Chico, T. J. A. (2019). Sodium nitroprusside prevents the detrimental effects of glucose on the neurovascular unit and behaviour in zebrafish. Disease Models \& Mechanisms, 12(9). https://doi.org/10.1242/dmm.039867

Crilly, S., Njegic, A., Laurie, S. E., Fotiou, E., Hudson, G., Barrington, J., Webb, K., Young, H. L., Badrock, A. P., Hurlstone, A., Rivers-Auty, J., Parry-Jones, A. R., Allan, S. M., \& Kasher, P. R. (2018). Using zebrafish larval models to study brain injury, locomotor and neuroinflammatory outcomes following intracerebral haemorrhage. F1000Research, 7, 1617. https://doi.org/10.12688/f1000research.16473.2

Cui, W. W., Low, S. E., Hirata, H., Saint-Amant, L., Geisler, R., Hume, R. I., \& Kuwada, J. Y. (2005). The zebrafish shocked gene encodes a glycine transporter and is essential for the function of early neural circuits in the CNS. The Journal of Neuroscience: The Official Journal of the Society for Neuroscience, 25(28), 6610-6620. https://doi.org/10.1523/JNEUROSCI.5009-04.2005

Dowd, F. J. (2017). Pharmacokinetics: The Absorption, Distribution, and Fate of Drugs. In Pharmacology and Therapeutics for Dentistry: Seventh Edition (pp. 15-43). Elsevier. https://doi.org/10.1016/B978-0-323-39307-2.00002-3

Du, W.-J., Zhang, R.-W., Li, J., Zhang, B.-B., Peng, X.-L., Cao, S., Yuan, J., Yuan, C.-D., Yu, T., \& Du, J.-L. (2018). The Locus Coeruleus Modulates Intravenous General Anesthesia of Zebrafish via a Cooperative Mechanism. Cell Reports, 24(12), 31463155.e3. https://doi.org/10.1016/j.celrep.2018.08.046

Duan, J., Yu, Y., Shi, H., Tian, L., Guo, C., Huang, P., Zhou, X., Peng, S., \& Sun, Z. (2013). Toxic effects of silica nanoparticles on zebrafish embryos and larvae. PloS One, 8(9), e74606. https://doi.org/10.1371/journal.pone.0074606

Dubey, S., Ganeshpurkar, A., Bansal, D., \& Dubey, N. (2015). Protective effect of rutin on impairment of cognitive functions of due to antiepileptic drugs on zebrafish model. Indian Journal of Pharmacology, 47(1), 86-89. https://doi.org/10.4103/02537613.150357 
Egan, R. J., Bergner, C. L., Hart, P. C., Cachat, J. M., Canavello, P. R., Elegante, M. F., Elkhayat, S. I., Bartels, B. K., Tien, A. K., Tien, D. H., Mohnot, S., Beeson, E., Glasgow, E., Amri, H., Zukowska, Z., \& Kalueff, A. V. (2009). Understanding behavioral and physiological phenotypes of stress and anxiety in zebrafish. Behavioural Brain Research, 205(1), 38-44. https://doi.org/10.1016/j.bbr.2009.06.022

Ek, F., Malo, M., Åberg Andersson, M., Wedding, C., Kronborg, J., Svensson, P., Waters, S., Petersson, P., \& Olsson, R. (2016). Behavioral Analysis of Dopaminergic Activation in Zebrafish and Rats Reveals Similar Phenotypes. ACS Chemical Neuroscience, 7(5), 633-646. https://doi.org/10.1021/acschemneuro.6b00014

Facchin, L., Duboué, E. R., \& Halpern, M. E. (2015). Disruption of Epithalamic Left-Right Asymmetry Increases Anxiety in Zebrafish. The Journal of Neuroscience: The Official Journal of the Society for Neuroscience, 35(48), 15847-15859. https://doi.org/10.1523/JNEUROSCI.2593-15.2015

Fernandes, Y., Tran, S., Abraham, E., \& Gerlai, R. (2014). Embryonic alcohol exposure impairs associative learning performance in adult zebrafish. Behavioural Brain Research, 265, 181-187. https://doi.org/10.1016/j.bbr.2014.02.035

Fitzgerald, J. A., Kirla, K. T., Zinner, C. P., \& Vom Berg, C. M. (2019). Emergence of consistent intra-individual locomotor patterns during zebrafish development. Scientific Reports, 9(1), 13647. https://doi.org/10.1038/s41598-019-49614-y

Formella, I., Scott, E. K., Burne, T. H. J., Harms, L. R., Liu, P.-Y., Turner, K. M., Cui, X., \& Eyles, D. W. (2012). Transient knockdown of tyrosine hydroxylase during development has persistent effects on behaviour in adult zebrafish (Danio rerio). PloS One, 7(8), e42482. https://doi.org/10.1371/journal.pone.0042482

Frank, D. F., Brander, S. M., Hasenbein, S., Harvey, D. J., Lein, P. J., Geist, J., \& Connon, R. E. (2019). Developmental exposure to environmentally relevant concentrations of bifenthrin alters transcription of $\mathrm{mTOR}$ and ryanodine receptor-dependent signaling molecules and impairs predator avoidance behavior across early life stages in inland silversides (Meni. Aquatic Toxicology (Amsterdam, Netherlands), 206, 1-13. https://doi.org/10.1016/j.aquatox.2018.10.014

Frank, D. F., Miller, G. W., Harvey, D. J., Brander, S. M., Geist, J., Connon, R. E., \& Lein, P. J. (2018). Bifenthrin causes transcriptomic alterations in mTOR and ryanodine receptor-dependent signaling and delayed hyperactivity in developing zebrafish (Danio rerio). Aquatic Toxicology (Amsterdam, Netherlands), 200, 50-61. https://doi.org/10.1016/j.aquatox.2018.04.003

García-González, J., Brock, A. J., Parker, M. O., Riley, R. J., Joliffe, D., Sudwarts, A., Teh, M. T., Busch-Nentwich, E. M., Stemple, D. L., Martineau, A. R., Kaprio, J., Palviainen, T., Kuan, V., Walton, R. T., \& Brennan, C. H. (2020). Identification of slit3 as a locus affecting nicotine preference in zebrafish and human smoking behaviour. ELife, 9. https://doi.org/10.7554/eLife.51295

Gauthier, P. T., \& Vijayan, M. M. (2018). Nonlinear mixed-modelling discriminates the effect of chemicals and their mixtures on zebrafish behavior. Scientific Reports, 8(1), 1999. https://doi.org/10.1038/s41598-018-20112-x

Gebauer, D. L., Pagnussat, N., Piato, A. L., Schaefer, I. C., Bonan, C. D., \& Lara, D. R. (2011). Effects of anxiolytics in zebrafish: similarities and differences between benzodiazepines, buspirone and ethanol. Pharmacology, Biochemistry, and Behavior, 99(3), 480-486. https://doi.org/10.1016/j.pbb.2011.04.021

Gehrig, J., Pandey, G., \& Westhoff, J. H. (2018). Zebrafish as a model for drug screening in genetic kidney diseases. In Frontiers in Pediatrics (Vol. 6, p. 183). Frontiers Media S.A. 
https://doi.org/10.3389/fped.2018.00183

Glazer, L., Hahn, M. E., \& Aluru, N. (2016). Delayed effects of developmental exposure to low levels of the aryl hydrocarbon receptor agonist 3,3',4,4',5-pentachlorobiphenyl (PCB126) on adult zebrafish behavior. Neurotoxicology, 52, 134-143. https://doi.org/10.1016/j.neuro.2015.11.012

Glazer, L., Wells, C. N., Drastal, M., Odamah, K.-A., Galat, R. E., Behl, M., \& Levin, E. D. (2018). Developmental exposure to low concentrations of two brominated flame retardants, BDE-47 and BDE-99, causes life-long behavioral alterations in zebrafish. Neurotoxicology, 66, 221-232. https://doi.org/10.1016/j.neuro.2017.09.007

González, E. A., Carty, D. R., Tran, F. D., Cole, A. M., \& Lein, P. J. (2018). Developmental exposure to silver nanoparticles at environmentally relevant concentrations alters swimming behavior in zebrafish (Danio rerio). Environmental Toxicology and Chemistry, 37(12), 3018-3024. https://doi.org/10.1002/etc.4275

Gonzalez, S. T., Remick, D., Creton, R., \& Colwill, R. M. (2016). Effects of embryonic exposure to polychlorinated biphenyls (PCBs) on anxiety-related behaviors in larval zebrafish. Neurotoxicology, 53, 93-101. https://doi.org/10.1016/j.neuro.2015.12.018

Grone, B. P., Qu, T., \& Baraban, S. C. (2017). Behavioral Comorbidities and Drug Treatments in a Zebrafish scn1lab Model of Dravet Syndrome. ENeuro, 4(4). https://doi.org/10.1523/ENEURO.0066-17.2017

Gutiérrez, H. C., Vacca, I., Schoenmacker, G., Cleal, M., Tochwin, A., O’Connor, B., Young, A. M. J., Vasquez, A. A., Winter, M. J., Parker, M. O., \& Norton, W. H. J. (2020). Screening for drugs to reduce zebrafish aggression identifies caffeine and sildenafil. European Neuropsychopharmacology, 30, 17-29. https://doi.org/10.1016/j.euroneuro.2019.10.005

Han, Y., Zheng, Y., Zhang, J., \& Hu, C. (2018). Neurobehavioral Effects of Cephalosporins: Assessment of Locomotors Activity, Motor and Sensory Development in Zebrafish. Frontiers in Pharmacology, 9, 160. https://doi.org/10.3389/fphar.2018.00160

He, Xiaowei, Gao, J., Dong, T., Chen, M., Zhou, K., Chang, C., Luo, J., Wang, C., Wang, S., Chen, D., Zhou, Z., Tian, Y., Xia, Y., \& Wang, X. (2016). Developmental Neurotoxicity of Methamidophos in the Embryo-Larval Stages of Zebrafish. International Journal of Environmental Research and Public Health, 14(1). https://doi.org/10.3390/ijerph14010023

He, Xiong, Zhong, Z.-M., \& Che, Y. (2012). [Locomotor activity and learning and memory abilities in Alzheimer's disease induced by aluminum in an acid environment in zebrafish]. Dong wu xue yan jiu = Zoological research, 33(2), 231-236. https://doi.org/10.3724/SP.J.1141.2012.02231

Heal, D. J., Smith, S. L., Gosden, J., \& Nutt, D. J. (2013). Amphetamine, past and present A pharmacological and clinical perspective. In Journal of Psychopharmacology (Vol. 27, Issue 6, pp. 479-496). SAGE Publications. https://doi.org/10.1177/0269881113482532

Holcombe, A., Schalomon, M., \& Hamilton, T. J. (2014). A novel method of drug administration to multiple zebrafish (Danio rerio) and the quantification of withdrawal. Journal of Visualized Experiments : JoVE, 93, e51851. https://doi.org/10.3791/51851

Hu, Z.-Y., Chen, B., Zhang, J.-P., \& Ma, Y.-Y. (2017). Up-regulation of autophagy-related gene 5 (ATG5) protects dopaminergic neurons in a zebrafish model of Parkinson's disease. The Journal of Biological Chemistry, 292(44), 18062-18074.

https://doi.org/10.1074/jbc.M116.764795 
Ikeda, H., Delargy, A. H., Yokogawa, T., Urban, J. M., Burgess, H. A., \& Ono, F. (2013). Intrinsic properties of larval zebrafish neurons in ethanol. PloS One, 8(5), e63318. https://doi.org/10.1371/journal.pone.0063318

Irons, T. D., Kelly, P. E., Hunter, D. L., Macphail, R. C., \& Padilla, S. (2013). Acute administration of dopaminergic drugs has differential effects on locomotion in larval zebrafish. Pharmacology, Biochemistry, and Behavior, 103(4), 792-813. https://doi.org/10.1016/j.pbb.2012.12.010

Irons, T. D., MacPhail, R. C., Hunter, D. L., \& Padilla, S. (2010). Acute neuroactive drug exposures alter locomotor activity in larval zebrafish. Neurotoxicology and Teratology, 32(1), 84-90. https://doi.org/10.1016/j.ntt.2009.04.066

Itskovits, E., Levine, A., Cohen, E., \& Zaslaver, A. (2017). A multi-animal tracker for studying complex behaviors. BMC Biology, 15(1), 29. https://doi.org/10.1186/s12915-017-0363-9

Jantzen, C. E., Annunziato, K. A., Bugel, S. M., \& Cooper, K. R. (2016). PFOS, PFNA, and PFOA sub-lethal exposure to embryonic zebrafish have different toxicity profiles in terms of morphometrics, behavior and gene expression. Aquatic Toxicology (Amsterdam, Netherlands), 175, 160-170. https://doi.org/10.1016/j.aquatox.2016.03.026

Jantzen, C. E., Annunziato, K. M., \& Cooper, K. R. (2016). Behavioral, morphometric, and gene expression effects in adult zebrafish (Danio rerio) embryonically exposed to PFOA, PFOS, and PFNA. Aquatic Toxicology (Amsterdam, Netherlands), 180, 123130. https://doi.org/10.1016/j.aquatox.2016.09.011

Jarema, K. A., Hunter, D. L., Shaffer, R. M., Behl, M., \& Padilla, S. (2015). Acute and developmental behavioral effects of flame retardants and related chemicals in zebrafish. Neurotoxicology and Teratology, 52(Pt B), 194-209. https://doi.org/10.1016/j.ntt.2015.08.010

Jensen, H. M., Korbut, R., Kania, P. W., \& Buchmann, K. (2018). Cannabidiol effects on behaviour and immune gene expression in zebrafish (Danio rerio). PloS One, 13(7), e0200016. https://doi.org/10.1371/journal.pone.0200016

Jia, L., Raghupathy, R. K., Albalawi, A., Zhao, Z., Reilly, J., Xiao, Q., \& Shu, X. (2017). A colour preference technique to evaluate acrylamide-induced toxicity in zebrafish. Comparative Biochemistry and Physiology. Toxicology \& Pharmacology : CBP, 199, 11-19. https://doi.org/10.1016/j.cbpc.2017.01.004

Kalueff, A. V. (2017). The rights and wrongs of zebrafish: Behavioral phenotyping of zebrafish. In The Rights and Wrongs of Zebrafish: Behavioral Phenotyping of Zebrafish. https://doi.org/10.1007/978-3-319-33774-6

Kalueff, A. V., Stewart, A. M., \& Gerlai, R. (2014). Zebrafish as an emerging model for studying complex brain disorders. Trends in Pharmacological Sciences, 35(2), 63-75. https://doi.org/10.1016/j.tips.2013.12.002

Kao, C.-J., Chen, W.-F., Guo, B.-L., Feng, C.-W., Hung, H.-C., Yang, W.-Y., Sung, C.-S., Tsui, K.-H., Chu, H., Chen, N.-F., \& Wen, Z.-H. (2017). The 1-Tosylpentan-3-one Protects against 6-Hydroxydopamine-Induced Neurotoxicity. International Journal of Molecular Sciences, 18(5). https://doi.org/10.3390/ijms18051096

Kasica, N., Podlasz, P., Sundvik, M., Tamas, A., Reglodi, D., \& Kaleczyc, J. (2016). Protective Effects of Pituitary Adenylate Cyclase-Activating Polypeptide (PACAP) Against Oxidative Stress in Zebrafish Hair Cells. Neurotoxicity Research, 30(4), 633647. https://doi.org/10.1007/s12640-016-9659-8 
Kedra, M., Banasiak, K., Kisielewska, K., Wolinska-Niziol, L., Jaworski, J., \& Zmorzynska, J. (2020). TrkB hyperactivity contributes to brain dysconnectivity, epileptogenesis, and anxiety in zebrafish model of Tuberous Sclerosis Complex. Proceedings of the National Academy of Sciences of the United States of America, 117(4), 2170-2179. https://doi.org/10.1073/pnas.1910834117

Klee, E. W., Ebbert, J. O., Schneider, H., Hurt, R. D., \& Ekker, S. C. (2011). Zebrafish for the Study of the Biological Effects of Nicotine. Nicotine \& Tobacco Research. https://doi.org/10.1093/ntr/ntr010

Knecht, A. L., Truong, L., Marvel, S. W., Reif, D. M., Garcia, A., Lu, C., Simonich, M. T., Teeguarden, J. G., \& Tanguay, R. L. (2017). Transgenerational inheritance of neurobehavioral and physiological deficits from developmental exposure to benzo[a]pyrene in zebrafish. Toxicology and Applied Pharmacology, 329, 148-157. https://doi.org/10.1016/j.taap.2017.05.033

Knogler, L. D., \& Drapeau, P. (2014). Sensory gating of an embryonic zebrafish interneuron during spontaneous motor behaviors. Frontiers in Neural Circuits, 8, 121. https://doi.org/10.3389/fncir.2014.00121

Knogler, L. D., Liao, M., \& Drapeau, P. (2010). Synaptic scaling and the development of a motor network. The Journal of Neuroscience: The Official Journal of the Society for Neuroscience, 30(26), 8871-8881. https://doi.org/10.1523/JNEUROSCI.0880-10.2010

Knogler, L. D., Ryan, J., Saint-Amant, L., \& Drapeau, P. (2014). A hybrid electrical/chemical circuit in the spinal cord generates a transient embryonic motor behavior. The Journal of Neuroscience : The Official Journal of the Society for Neuroscience, 34(29), 96449655. https://doi.org/10.1523/JNEUROSCI.1225-14.2014

Ko, M. J., Ganzen, L. C., Coskun, E., Mukadam, A. A., Leung, Y. F., \& van Rijn, R. M. (2019). A critical evaluation of TRPA1-mediated locomotor behavior in zebrafish as a screening tool for novel anti-nociceptive drug discovery. Scientific Reports, 9(1), 2430. https://doi.org/10.1038/s41598-019-38852-9

Kopp, R., Legler, J., \& Legradi, J. (2018). Alterations in locomotor activity of feeding zebrafish larvae as a consequence of exposure to different environmental factors. Environmental Science and Pollution Research International, 25(5), 4085-4093. https://doi.org/10.1007/s11356-016-6704-3

Kristofco, L. A., Cruz, L. C., Haddad, S. P., Behra, M. L., Chambliss, C. K., \& Brooks, B. W. (2016). Age matters: Developmental stage of Danio rerio larvae influences photomotor response thresholds to diazinion or diphenhydramine. Aquatic Toxicology (Amsterdam, Netherlands), 170, 344-354. https://doi.org/10.1016/j.aquatox.2015.09.011

Kundap, U. P., Kumari, Y., Othman, I., \& Shaikh, M. F. (2017). Zebrafish as a Model for Epilepsy-Induced Cognitive Dysfunction: A Pharmacological, Biochemical and Behavioral Approach. Frontiers in Pharmacology, 8, 515. https://doi.org/10.3389/fphar.2017.00515

Kyriakatos, A., Mahmood, R., Ausborn, J., Porres, C. P., Büschges, A., \& El Manira, A. (2011). Initiation of locomotion in adult zebrafish. The Journal of Neuroscience: The Official Journal of the Society for Neuroscience, 31(23), 8422-8431. https://doi.org/10.1523/JNEUROSCI.1012-11.2011

Kyzar, E., Stewart, A. M., Landsman, S., Collins, C., Gebhardt, M., Robinson, K., \& Kalueff, A. V. (2013). Behavioral effects of bidirectional modulators of brain monoamines reserpine and d-amphetamine in zebrafish. Brain Research, 1527, 108-116. https://doi.org/10.1016/j.brainres.2013.06.033 
Lambert, A. M., Bonkowsky, J. L., \& Masino, M. A. (2012). The Conserved Dopaminergic Diencephalospinal Tract Mediates Vertebrate Locomotor Development in Zebrafish Larvae. Journal of Neuroscience. https://doi.org/10.1523/JNEUROSCI.1638-12.2012

Lange, M., Froc, C., Grunwald, H., Norton, W. H. J., \& Bally-Cuif, L. (2018). Pharmacological analysis of zebrafish Iphn3.1 morphant larvae suggests that saturated dopaminergic signaling could underlie the ADHD-like locomotor hyperactivity. Progress in NeuroPsychopharmacology \& Biological Psychiatry, 84(Pt A), 181-189. https://doi.org/10.1016/j.pnpbp.2018.02.010

Li, F., Lin, J., Liu, X., Li, W., Ding, Y., Zhang, Y., Zhou, S., Guo, N., \& Li, Q. (2018). Characterization of the locomotor activities of zebrafish larvae under the influence of various neuroactive drugs. Annals of Translational Medicine, 6(10), 173. https://doi.org/10.21037/atm.2018.04.25

Li, J., Zhang, Y., Liu, K., He, Q., Sun, C., Han, J., Han, L., \& Tian, Q. (2018). Xiaoaiping Induces Developmental Toxicity in Zebrafish Embryos Through Activation of ER Stress, Apoptosis and the Wnt Pathway. Frontiers in Pharmacology, 9, 1250. https://doi.org/10.3389/fphar.2018.01250

Li, X., Li, X., Li, Y.-X., Zhang, Y., Chen, D., Sun, M.-Z., Zhao, X., Chen, D.-Y., \& Feng, X.-Z. (2015). The Difference between Anxiolytic and Anxiogenic Effects Induced by Acute and Chronic Alcohol Exposure and Changes in Associative Learning and Memory Based on Color Preference and the Cause of Parkinson-Like Behaviors in Zebrafish. PloS One, 10(11), e0141134. https://doi.org/10.1371/journal.pone.0141134

Li, X., Liu, B., Li, X.-L., Li, Y.-X., Sun, M.-Z., Chen, D.-Y., Zhao, X., \& Feng, X.-Z. (2014). $\mathrm{SiO} 2$ nanoparticles change colour preference and cause Parkinson's-like behaviour in zebrafish. Scientific Reports, 4, 3810. https://doi.org/10.1038/srep03810

Liao, Q., Gong, G., Siu, S. W. I., Wong, C. T. T., Yu, H., Tse, Y. C., Rádis-Baptista, G., \& Lee, S. M.-Y. (2018). A Novel ShK-Like Toxic Peptide from the Transcriptome of the Cnidarian Palythoa caribaeorum Displays Neuroprotection and Cardioprotection in Zebrafish. Toxins, 10(6). https://doi.org/10.3390/toxins10060238

Lieschke, G. J., \& Currie, P. D. (2007). Animal models of human disease: zebrafish swim into view. Nature Reviews Genetics, 8(5), 353-367. https://doi.org/10.1038/nrg2091

Liu, C.-X., Li, C.-Y., Hu, C.-C., Wang, Y., Lin, J., Jiang, Y.-H., Li, Q., \& Xu, X. (2018). CRISPR/Cas9-induced shank3b mutant zebrafish display autism-like behaviors. Molecular Autism, 9, 23. https://doi.org/10.1186/s13229-018-0204-x

Liu, X., Zhang, Y., Lin, J., Xia, Q., Guo, N., \& Li, Q. (2016). Social Preference Deficits in Juvenile Zebrafish Induced by Early Chronic Exposure to Sodium Valproate. Frontiers in Behavioral Neuroscience, 10, 201. https://doi.org/10.3389/fnbeh.2016.00201

Liu, Y., Ma, P., Cassidy, P. A., Carmer, R., Zhang, G., Venkatraman, P., Brown, S. A., Pang, C. P., Zhong, W., Zhang, M., \& Leung, Y. F. (2017). Statistical Analysis of Zebrafish Locomotor Behaviour by Generalized Linear Mixed Models. Scientific Reports, 7(1), 2937. https://doi.org/10.1038/s41598-017-02822-w

Lobao-Soares, B., Eduardo-da-Silva, P., Amarilha, H., Pinheiro-da-Silva, J., Silva, P. F., \& Luchiari, A. C. (2018). It's Tea Time: Interference of Ayahuasca Brew on Discriminative Learning in Zebrafish. Frontiers in Behavioral Neuroscience, 12, 190. https://doi.org/10.3389/fnbeh.2018.00190

Long, S.-M., Liang, F.-Y., Wu, Q., Lu, X.-L., Yao, X.-L., Li, S.-C., Li, J., Su, H., Pang, J.-Y., \& Pei, Z. (2014). Identification of marine neuroactive molecules in behaviour-based screens in the larval zebrafish. Marine Drugs, 12(6), 3307-3322. 
https://doi.org/10.3390/md12063307

Lopez-Luna, J., Al-Jubouri, Q., Al-Nuaimy, W., \& Sneddon, L. U. (2017). Reduction in activity by noxious chemical stimulation is ameliorated by immersion in analgesic drugs in zebrafish. Journal of Experimental Biology, 220(8), 1451-1458.

https://doi.org/10.1242/jeb.146969

Lovely, C. Ben, Fernandes, Y., \& Eberhart, J. K. (2016). Fishing for Fetal Alcohol Spectrum Disorders: Zebrafish as a Model for Ethanol Teratogenesis. Zebrafish. https://doi.org/10.1089/zeb.2016.1270

Luchtenburg, F. J., Schaaf, M. J. M., \& Richardson, M. K. (2019). Functional characterization of the cannabinoid receptors 1 and 2 in zebrafish larvae using behavioral analysis. Psychopharmacology, 236(7), 2049-2058. https://doi.org/10.1007/s00213-019-05193-4

Maaswinkel, H., Le, X., He, L., Zhu, L., \& Weng, W. (2013). Dissociating the effects of habituation, black walls, buspirone and ethanol on anxiety-like behavioral responses in shoaling zebrafish. A 3D approach to social behavior. Pharmacology, Biochemistry, and Behavior, 108, 16-27. https://doi.org/10.1016/j.pbb.2013.04.009

Maaswinkel, H., Zhu, L., \& Weng, W. (2013). Using an automated 3D-tracking system to record individual and shoals of adult zebrafish. Journal of Visualized Experiments : JoVE, 82, 50681. https://doi.org/10.3791/50681

Macrì, S., Clément, R. J. G., Spinello, C., \& Porfiri, M. (2019). Comparison between two- and three-dimensional scoring of zebrafish response to psychoactive drugs: identifying when three-dimensional analysis is needed. PeerJ, 7, e7893. https://doi.org/10.7717/peerj.7893

Makhija, D. T., \& Jagtap, A. G. (2014). Studies on sensitivity of zebrafish as a model organism for Parkinson's disease: Comparison with rat model. Journal of Pharmacology \& Pharmacotherapeutics, 5(1), 39-46. https://doi.org/10.4103/0976500X.124422

Maximino, C., da Silva, A. W. B., Gouveia, A. J., \& Herculano, A. M. (2011). Pharmacological analysis of zebrafish (Danio rerio) scototaxis. Progress in NeuroPsychopharmacology \& Biological Psychiatry, 35(2), 624-631. https://doi.org/10.1016/j.pnpbp.2011.01.006

Maximino, C., Lima, M. G., Olivera, K. R. M., Picanço-Diniz, D. L. W., \& Herculano, A. M. (2011). Adenosine A1, but not A2, Receptor Blockade Increases Anxiety and Arousal in Zebrafish. Basic \& Clinical Pharmacology \& Toxicology, 109(3), 203-207. https://doi.org/10.1111/j.1742-7843.2011.00710.x

McDearmid, J. R., \& Drapeau, P. (2006). Rhythmic motor activity evoked by NMDA in the spinal zebrafish larva. Journal of Neurophysiology, 95(1), 401-417. https://doi.org/10.1152/jn.00844.2005

McLean, D. L., Masino, M. A., Koh, I. Y. Y., Lindquist, W. B., \& Fetcho, J. R. (2008). Continuous shifts in the active set of spinal interneurons during changes in locomotor speed. Nature Neuroscience, 11(12), 1419-1429. https://doi.org/10.1038/nn.2225

Menelaou, E., Udvadia, A. J., Tanguay, R. L., \& Svoboda, K. R. (2014). Activation of a2Acontaining nicotinic acetylcholine receptors mediates nicotine-induced motor output in embryonic zebrafish. The European Journal of Neuroscience, 40(1), 2225-2240. https://doi.org/10.1111/ejn.12591

Mirat, O., Sternberg, J. R., Severi, K. E., \& Wyart, C. (2013). ZebraZoom: an automated program for high-throughput behavioral analysis and categorization. Frontiers in Neural 
Circuits, 7, 107. https://doi.org/10.3389/fncir.2013.00107

Misztal, K., Brozko, N., Nagalski, A., Szewczyk, L. M., Krolak, M., Brzozowska, K., Kuznicki, J., \& Wisniewska, M. B. (2017). TCF7L2 mediates the cellular and behavioral response to chronic lithium treatment in animal models. Neuropharmacology, 113(Pt A), 490501. https://doi.org/10.1016/j.neuropharm.2016.10.027

Mitra, A., \& Kesisoglou, F. (2013). Impaired Drug Absorption Due to High Stomach pH: A Review of Strategies for Mitigation of Such Effect To Enable Pharmaceutical Product Development. https://doi.org/10.1021/mp400256h

Mora-Zamorano, F. X., Svoboda, K. R., \& Carvan, M. J. 3rd. (2016). The Nicotine-Evoked Locomotor Response: A Behavioral Paradigm for Toxicity Screening in Zebrafish (Danio rerio) Embryos and Eleutheroembryos Exposed to Methylmercury. PloS One, 11(4), e0154570. https://doi.org/10.1371/journal.pone.0154570

Morbiato, E., Bilel, S., Tirri, M., Arfè, R., Fantinati, A., Savchuk, S., Appolonova, S., Frisoni, P., Tagliaro, F., Neri, M., Grignolio, S., Bertolucci, C., \& Marti, M. (2020). Potential of the zebrafish model for the forensic toxicology screening of NPS: A comparative study of the effects of APINAC and methiopropamine on the behavior of zebrafish larvae and mice. Neurotoxicology, 78, 36-46. https://doi.org/10.1016/j.neuro.2020.02.003

Mu, Y., Li, X., Zhang, B., \& Du, J. (2012). Visual input modulates audiomotor function via hypothalamic dopaminergic neurons through a cooperative mechanism. Neuron, 75(4), 688-699. https://doi.org/10.1016/j.neuron.2012.05.035

Nakamachi, T., Tanigawa, A., Konno, N., Shioda, S., \& Matsuda, K. (2019). Expression Patterns of PACAP and PAC1R Genes and Anorexigenic Action of PACAP1 and PACAP2 in Zebrafish. Frontiers in Endocrinology, 10, 227. https://doi.org/10.3389/fendo.2019.00227

National Center for Biotechnology Information. (2020). Caffeine Compound Summary. PubChem Database. https://doi.org/10.5517/CCNH4QZ

Norton, W. H. J. W. H. (2013). Toward developmental models of psychiatric disorders in zebrafish. 7, 79. https://doi.org/10.3389/fncir.2013.00079

Nowicki, M., Tran, S., Chatterjee, D., \& Gerlai, R. (2015). Inhibition of phosphorylated tyrosine hydroxylase attenuates ethanol-induced hyperactivity in adult zebrafish (Danio rerio). Pharmacology Biochemistry and Behavior. https://doi.org/10.1016/j.pbb.2015.09.008

Oldendorf, W. H. (1974). Lipid Solubility and Drug Penetration of the Blood Brain Barrier. Experimental Biology and Medicine, 147(3), 813-816. https://doi.org/10.3181/00379727-147-38444

Oldendorf, William H., Stoller, B. E., \& Harris, F. L. (1993). Blood-brain barrier penetration abolished by N-methyl quaternization of nicotine. Proceedings of the National Academy of Sciences of the United States of America, 90(1), 307-311. https://doi.org/10.1073/pnas.90.1.307

Oliveri, A N, Bailey, J. M., \& Levin, E. D. (2015). Developmental exposure to organophosphate flame retardants causes behavioral effects in larval and adult zebrafish. Neurotoxicology and Teratology, 52(Pt B), 220-227. https://doi.org/10.1016/j.ntt.2015.08.008

Oliveri, Anthony N., \& Levin, E. D. (2019). Dopamine D1 and D2 receptor antagonism during development alters later behavior in zebrafish. Behavioural Brain Research, 356, 250256. https://doi.org/10.1016/j.bbr.2018.08.028 
Oliveri, Anthony N, Ortiz, E., \& Levin, E. D. (2018). Developmental exposure to an organophosphate flame retardant alters later behavioral responses to dopamine antagonism in zebrafish larvae. Neurotoxicology and Teratology, 67, 25-30. https://doi.org/10.1016/j.ntt.2018.03.002

Palmér, T., Ek, F., Enqvist, O., Olsson, R., Åström, K., \& Petersson, P. (2017). Action sequencing in the spontaneous swimming behavior of zebrafish larvae - implications for drug development. Scientific Reports, 7(1), 3191. https://doi.org/10.1038/s41598017-03144-7

Pandelides, Z., Thornton, C., Lovitt, K. G., Faruque, A. S., Whitehead, A. P., Willett, K. L., \& Ashpole, N. M. (2020). Developmental exposure to $\Delta(9)$-tetrahydrocannabinol (THC) causes biphasic effects on longevity, inflammation, and reproduction in aged zebrafish (Danio rerio). GeroScience, 42(3), 923-936. https://doi.org/10.1007/s11357-020-001753

Pant, D. C., Dorboz, I., Schluter, A., Fourcade, S., Launay, N., Joya, J., Aguilera-Albesa, S., Yoldi, M. E., Casasnovas, C., Willis, M. J., Ruiz, M., Ville, D., Lesca, G., Siquier-Pernet, K., Desguerre, I., Yan, H., Wang, J., Burmeister, M., Brady, L., ... Pujol, A. (2019). Loss of the sphingolipid desaturase DEGS1 causes hypomyelinating leukodystrophy. The Journal of Clinical Investigation, 129(3), 1240-1256. https://doi.org/10.1172/JCl123959

Parker, M. O., Brock, A. J., Walton, R. T., \& Brennan, C. H. (2013). The role of zebrafish (Danio rerio) in dissecting the genetics and neural circuits of executive function. Frontiers in Neural Circuits, 7. https://doi.org/10.3389/fncir.2013.00063

Peng, J., Wagle, M., Mueller, T., Mathur, P., Lockwood, B. L., Bretaud, S., \& Guo, S. (2009). Ethanol-modulated camouflage response screen in zebrafish uncovers a novel role for cAMP and extracellular signal-regulated kinase signaling in behavioral sensitivity to ethanol. The Journal of Neuroscience : The Official Journal of the Society for Neuroscience, 29(26), 8408-8418. https://doi.org/10.1523/JNEUROSCI.0714-09.2009

Petzold, A. M., Balciunas, D., Sivasubbu, S., Clark, K. J., Bedell, V. M., Westcot, S. E., Myers, S. R., Moulder, G. L., Thomas, M. J., \& Ekker, S. C. (2009). Nicotine response genetics in the zebrafish. Proceedings of the National Academy of Sciences of the United States of America, 106(44), 18662-18667.

https://doi.org/10.1073/pnas.0908247106

Pham, D.-H., De Roo, B., Nguyen, X.-B., Vervaele, M., Kecskés, A., Ny, A., Copmans, D., Vriens, H., Locquet, J.-P., Hoet, P., \& de Witte, P. A. M. (2016). Use of Zebrafish Larvae as a Multi-Endpoint Platform to Characterize the Toxicity Profile of Silica Nanoparticles. Scientific Reports, 6, 37145. https://doi.org/10.1038/srep37145

Pietri, T., Manalo, E., Ryan, J., Saint-Amant, L., \& Washbourne, P. (2009). Glutamate drives the touch response through a rostral loop in the spinal cord of zebrafish embryos. Developmental Neurobiology, 69(12), 780-795. https://doi.org/10.1002/dneu.20741

Pogocki, D., Ruman, T., Danilczuk, M., Danilczuk, M., Celuch, M., \& Wałajtys-Rode, E. (2007). Application of nicotine enantiomers, derivatives and analogues in therapy of neurodegenerative disorders. In European Journal of Pharmacology (Vol. 563, Issues 1-3, pp. 18-39). Elsevier. https://doi.org/10.1016/j.ejphar.2007.02.038

Pruvot, B., Quiroz, Y., Voncken, A., Jeanray, N., Piot, A., Martial, J. A., \& Muller, M. (2012). A panel of biological tests reveals developmental effects of pharmaceutical pollutants on late stage zebrafish embryos. Reproductive Toxicology (Elmsford, N.Y.), 34(4), 568583. https://doi.org/10.1016/j.reprotox.2012.07.010

Puttonen, H. A. J., Sundvik, M., Rozov, S., Chen, Y.-C., \& Panula, P. (2013). Acute ethanol treatment upregulates Th1, Th2, and Hdc in larval zebrafish in stable networks. 
Frontiers in Neural Circuits, 7, 102. https://doi.org/10.3389/fncir.2013.00102

Radev, Z., Hermel, J.-M., Elipot, Y., Bretaud, S., Arnould, S., Duchateau, P., Ruggiero, F., Joly, J.-S., \& Sohm, F. (2015). A TALEN-Exon Skipping Design for a Bethlem Myopathy Model in Zebrafish. PloS One, 10(7), e0133986.

https://doi.org/10.1371/journal.pone.0133986

Rihel, J., Prober, D. A., Arvanites, A., Lam, K., Zimmerman, S., Jang, S., Haggarty, S. J., Kokel, D., Rubin, L. L., Peterson, R. T., \& Schier, A. F. (2010). Zebrafish behavioral profiling links drugs to biological targets and rest/wake regulation. Science (New York, N.Y.), 327(5963), 348-351. https://doi.org/10.1126/science.1183090

Saili, K. S., Corvi, M. M., Weber, D. N., Patel, A. U., Das, S. R., Przybyla, J., Anderson, K. A., \& Tanguay, R. L. (2012). Neurodevelopmental low-dose bisphenol A exposure leads to early life-stage hyperactivity and learning deficits in adult zebrafish. Toxicology, 291(1-3), 83-92. https://doi.org/10.1016/j.tox.2011.11.001

Saint-Amant, L., \& Drapeau, P. (2000). Motoneuron activity patterns related to the earliest behavior of the zebrafish embryo. The Journal of Neuroscience: The Official Journal of the Society for Neuroscience, 20(11), 3964-3972.

https://doi.org/10.1523/JNEUROSCI.20-11-03964.2000

Sallinen, V, Torkko, V., Sundvik, M., Reenilä, I., Khrustalyov, D., Kaslin, J., \& Panula, P. (2009). MPTP and MPP+ target specific aminergic cell populations in larval zebrafish. Journal of Neurochemistry, 108(3), 719-731. https://doi.org/10.1111/j.14714159.2008.05793.x

Sallinen, Ville, Sundvik, M., Reenilä, I., Peitsaro, N., Khrustalyov, D., Anichtchik, O., Toleikyte, G., Kaslin, J., \& Panula, P. (2009). Hyperserotonergic phenotype after monoamine oxidase inhibition in larval zebrafish. Journal of Neurochemistry, 109(2), 403-415. https://doi.org/10.1111/j.1471-4159.2009.05986.x

Sarasamma, S., Audira, G., Juniardi, S., Sampurna, B. P., Lai, Y.-H., Hao, E., Chen, J.-R., \& Hsiao, C.-D. (2018). Evaluation of the Effects of Carbon 60 Nanoparticle Exposure to Adult Zebrafish: A Behavioral and Biochemical Approach to Elucidate the Mechanism of Toxicity. International Journal of Molecular Sciences, 19(12). https://doi.org/10.3390/ijms19123853

Sarasamma, S., Audira, G., Samikannu, P., Juniardi, S., Siregar, P., Hao, E., Chen, J.-R., \& Hsiao, C.-D. (2019). Behavioral Impairments and Oxidative Stress in the Brain, Muscle, and Gill Caused by Chronic Exposure of C(70) Nanoparticles on Adult Zebrafish. International Journal of Molecular Sciences, 20(22). https://doi.org/10.3390/ijms20225795

Savoldi, R., Polari, D., Pinheiro-da-Silva, J., Silva, P. F., Lobao-Soares, B., Yonamine, M., Freire, F. A. M., \& Luchiari, A. C. (2017). Behavioral Changes Over Time Following Ayahuasca Exposure in Zebrafish. Frontiers in Behavioral Neuroscience, 11, 139. https://doi.org/10.3389/fnbeh.2017.00139

Schepers, R. J. F., Oyler, J. M., Joseph, R. E., Cone, E. J., Moolchan, E. T., \& Huestis, M. A. (2003). Methamphetamine and amphetamine pharmacokinetics in oral fluid and plasma after controlled oral methamphetamine administration to human volunteers. Clinical Chemistry, 49(1), 121-132. https://doi.org/10.1373/49.1.121

Seebacher, F., Little, A. G., \& James, R. S. (2015). Skeletal muscle contractile function predicts activity and behaviour in zebrafish. The Journal of Experimental Biology, 218(Pt 24), 3878-3884. https://doi.org/10.1242/jeb.129049

Shimada, Y., Hirano, M., Nishimura, Y., \& Tanaka, T. (2012). A high-throughput 
fluorescence-based assay system for appetite-regulating gene and drug screening. PloS One, 7(12), e52549. https://doi.org/10.1371/journal.pone.0052549

Shontz, E. C., Souders, C. L. 2nd, Schmidt, J. T., \& Martyniuk, C. J. (2018). Domperidone upregulates dopamine receptor expression and stimulates locomotor activity in larval zebrafish (Danio rerio). Genes, Brain, and Behavior, 17(4), e12460. https://doi.org/10.1111/gbb.12460

Souders, C. L. 2nd, Davis, R. H., Qing, H., Liang, X., Febo, M., \& Martyniuk, C. J. (2019). The psychoactive cathinone derivative pyrovalerone alters locomotor activity and decreases dopamine receptor expression in zebrafish (Danio rerio). Brain and Behavior, 9(11), e01420. https://doi.org/10.1002/brb3.1420

Sourbron, J., Partoens, M., Scheldeman, C., Zhang, Y., Lagae, L., \& de Witte, P. (2019). Drug repurposing for Dravet syndrome in scn1 Lab(-/-) mutant zebrafish. Epilepsia, 60(2), e8-e13. https://doi.org/10.1111/epi.14647

Spector, R., \& Goldberg, M. J. (1982). Active Transport of Nicotine by the Isolated Choroid Plexus In Vitro. Journal of Neurochemistry, 38(2), 594-596. https://doi.org/10.1111/j.1471-4159.1982.tb08669.x

Sterling, M. E., Chang, G.-Q., Karatayev, O., Chang, S. Y., \& Leibowitz, S. F. (2016). Effects of embryonic ethanol exposure at low doses on neuronal development, voluntary ethanol consumption and related behaviors in larval and adult zebrafish: Role of hypothalamic orexigenic peptides. Behavioural Brain Research, 304, 125-138. https://doi.org/10.1016/j.bbr.2016.01.013

Sterling, M. E., Karatayev, O., Chang, G.-Q., Algava, D. B., \& Leibowitz, S. F. (2015). Model of voluntary ethanol intake in zebrafish: effect on behavior and hypothalamic orexigenic peptides. Behavioural Brain Research, 278, 29-39. https://doi.org/10.1016/j.bbr.2014.09.024

Sternberg, J. R., Severi, K. E., Fidelin, K., Gomez, J., Ihara, H., Alcheikh, Y., Hubbard, J. M., Kawakami, K., Suster, M., \& Wyart, C. (2016). Optimization of a Neurotoxin to Investigate the Contribution of Excitatory Interneurons to Speed Modulation In Vivo. Current Biology : CB, 26(17), 2319-2328. https://doi.org/10.1016/j.cub.2016.06.037

Stevens, E. D., \& Balahura, R. J. (2007). Comparative Medicine Aspects of Morphine Chemistry Important to Persons Working with Cold-blooded Animals, Especially Fish.

Stevens, J. S., Padilla, S., DeMarini, D. M., Hunter, D. L., Martin, W. K., Thompson, L. C., Gilmour, M. I., Hazari, M. S., \& Farraj, A. K. (2018). Zebrafish Locomotor Responses Reveal Irritant Effects of Fine Particulate Matter Extracts and a Role for TRPA1. Toxicological Sciences : An Official Journal of the Society of Toxicology, 161(2), 290299. https://doi.org/10.1093/toxsci/kfx217

Stewart, A M, Ullmann, J. F. P., Norton, W. H. J., Parker, M. O., Brennan, C. H., Gerlai, R., \& Kalueff, A. V. (2015). Molecular psychiatry of zebrafish. Molecular Psychiatry. https://doi.org/10.1038/mp.2014.128

Stewart, Adam Michael, Braubach, O., Spitsbergen, J., Gerlai, R., \& Kalueff, A. V. (2014). Zebrafish models for translational neuroscience research: From tank to bedside. In Trends in Neurosciences. https://doi.org/10.1016/j.tins.2014.02.011

Strähle, U., Geisler, R., Greiner, P., Hollert, H., Rastegar, S., Schumacher, A., Selderslaghs, I., Weiss, C., Witters, H., \& Braunbeck, T. (2012). Zebrafish embryos as an alternative to animal experiments-A commentary on the definition of the onset of protected life stages in animal welfare regulations. Reproductive Toxicology, 33(2), 128-132. https://doi.org/10.1016/J.REPROTOX.2011.06.121 
Sun, Y., Zhang, G., He, Z., Wang, Y., Cui, J., \& Li, Y. (2016). Effects of copper oxide nanoparticles on developing zebrafish embryos and larvae. International Journal of Nanomedicine, 11, 905-918. https://doi.org/10.2147/IJN.S100350

Švorc, L'. (2013). Determination of Caffeine: A Comprehensive Review on Electrochemical Methods. In Int. J. Electrochem. Sci (Vol. 8). www.electrochemsci.org

Tega, Y., Yamazaki, Y., Akanuma, S. ichi, Kubo, Y., \& Hosoya, K. ichi. (2018). Impact of nicotine transport across the blood-brain barrier: Carrier-mediated transport of nicotine and interaction with central nervous system drugs. In Biological and Pharmaceutical Bulletin (Vol. 41, Issue 9, pp. 1330-1336). Pharmaceutical Society of Japan. https://doi.org/10.1248/bpb.b18-00134

Thirumalai, V., \& Cline, H. T. (2008). Endogenous dopamine suppresses initiation of swimming in prefeeding zebrafish larvae. Journal of Neurophysiology, 100(3), 16351648. https://doi.org/10.1152/jn.90568.2008

Tomar, Scott, E., \& Henningfield, Jack, E. (1997). Review of the evident that pH is a determinant of nicotine dosage from oral use of smokeless tobacco. Group.Bmj.Com on October, 6, 219-225. http://tobaccocontrol.bmj.com/

Tran, S., \& Gerlai, R. (2013). Time-course of behavioural changes induced by ethanol in zebrafish (Danio rerio). Behavioural Brain Research, 252, 204-213. https://doi.org/10.1016/j.bbr.2013.05.065

Truong, L., Saili, K. S., Miller, J. M., Hutchison, J. E., \& Tanguay, R. L. (2012). Persistent adult zebrafish behavioral deficits results from acute embryonic exposure to gold nanoparticles. Comparative Biochemistry and Physiology. Toxicology \& Pharmacology: CBP, 155(2), 269-274. https://doi.org/10.1016/j.cbpc.2011.09.006

Turrini, L., Fornetto, C., Marchetto, G., Müllenbroich, M. C., Tiso, N., Vettori, A., Resta, F., Masi, A., Mannaioni, G., Pavone, F. S., \& Vanzi, F. (2017). Optical mapping of neuronal activity during seizures in zebrafish. Scientific Reports, 7(1), 3025.

https://doi.org/10.1038/s41598-017-03087-z

Vaz, R. L., Outeiro, T. F., \& Ferreira, J. J. (2018). Zebrafish as an animal model for drug discovery in Parkinson's disease and other movement disorders: A systematic review. In Frontiers in Neurology (Vol. 9, Issue JUN, p. 347). Frontiers Media S.A. https://doi.org/10.3389/fneur.2018.00347

Vignet, C., Joassard, L., Lyphout, L., Guionnet, T., Goubeau, M., Le Menach, K., Brion, F., Kah, O., Chung, B.-C., Budzinski, H., Bégout, M.-L., \& Cousin, X. (2015). Exposures of zebrafish through diet to three environmentally relevant mixtures of PAHs produce behavioral disruptions in unexposed F1 and F2 descendant. Environmental Science and Pollution Research International, 22(21), 16371-16383.

https://doi.org/10.1007/s11356-015-4157-8

Völgyi, G., Baka, E., Box, K. J., Comer, J. E. A., \& Takács-Novák, K. (2010). Study of pHdependent solubility of organic bases. Revisit of Henderson-Hasselbalch relationship. Analytica Chimica Acta, 673(1), 40-46. https://doi.org/10.1016/j.aca.2010.05.022

Wang, B., Dong, J., Xiao, H., Li, Y., Jin, Y., Cui, M., Zhang, S.-Q., \& Fan, S.-J. (2020). Metformin fights against radiation-induced early developmental toxicity. The Science of the Total Environment, 732, 139274. https://doi.org/10.1016/j.scitotenv.2020.139274

Wang, Y., Zhang, Y., Li, X., Sun, M., Wei, Z., Wang, Y., Gao, A., Chen, D., Zhao, X., \& Feng, X. (2015). Exploring the Effects of Different Types of Surfactants on Zebrafish Embryos and Larvae. Scientific Reports, 5, 10107. https://doi.org/10.1038/srep10107 
Ward, B. K., Tan, G. X.-J., Roberts, D. C., Della Santina, C. C., Zee, D. S., \& Carey, J. P. (2014). Strong static magnetic fields elicit swimming behaviors consistent with direct vestibular stimulation in adult zebrafish. PloS One, 9(3), e92109.

https://doi.org/10.1371/journal.pone.0092109

Weuring, W. J., Singh, S., Volkers, L., Rook, M. B., van 't Slot, R. H., Bosma, M., Inserra, M., Vetter, I., Verhoeven-Duif, N. M., Braun, K. P. J., Rivara, M., \& Koeleman, B. P. C. (2020). NaV1.1 and NaV1.6 selective compounds reduce the behavior phenotype and epileptiform activity in a novel zebrafish model for Dravet Syndrome. PloS One, 15(3), e0219106. https://doi.org/10.1371/journal.pone.0219106

Wilson, K. S., Tucker, C. S., Al-Dujaili, E. A. S., Holmes, M. C., Hadoke, P. W. F., Kenyon, C. J., \& Denvir, M. A. (2016). Early-life glucocorticoids programme behaviour and metabolism in adulthood in zebrafish. The Journal of Endocrinology, 230(1), 125-142. https://doi.org/10.1530/JOE-15-0376

Woods, I. G., Schoppik, D., Shi, V. J., Zimmerman, S., Coleman, H. A., Greenwood, J., Soucy, E. R., \& Schier, A. F. (2014). Neuropeptidergic signaling partitions arousal behaviors in zebrafish. The Journal of Neuroscience: The Official Journal of the Society for Neuroscience, 34(9), 3142-3160. https://doi.org/10.1523/JNEUROSCI.352913.2014

Xie, R., Zhang, M., Venkatraman, P., Zhang, X., Zhang, G., Carmer, R., Kantola, S. A., Pang, C. P., Ma, P., Zhang, M., Zhong, W., \& Leung, Y. F. (2019). Normalization of large-scale behavioural data collected from zebrafish. PloS One, 14(2), e0212234. https://doi.org/10.1371/journal.pone.0212234

Yoo, M. H., Rah, Y. C., Park, S., Koun, S., Im, G. J., Chae, S. W., Jung, H. H., \& Choi, J. (2018). Impact of nicotine exposure on hair cell toxicity and embryotoxicity during Zebrafish development. Clinical and Experimental Otorhinolaryngology, 11(2), 109117. https://doi.org/10.21053/ceo.2017.00857

Zabinyakov, N., Bullivant, G., Cao, F., Fernandez Ojeda, M., Jia, Z. P., Wen, X.-Y., Dowling, J. J., Salomons, G. S., \& Mercimek-Andrews, S. (2017). Characterization of the first knock-out aldh7a1 zebrafish model for pyridoxine-dependent epilepsy using CRISPRCas9 technology. PloS One, 12(10), e0186645.

https://doi.org/10.1371/journal.pone.0186645

Zada, D., Tovin, A., Lerer-Goldshtein, T., Vatine, G. D., \& Appelbaum, L. (2014). Altered behavioral performance and live imaging of circuit-specific neural deficiencies in a zebrafish model for psychomotor retardation. PLoS Genetics, 10(9), e1004615. https://doi.org/10.1371/journal.pgen.1004615

Zhang, S., Liu, X., Sun, M., Zhang, Q., Li, T., Li, X., Xu, J., Zhao, X., Chen, D., \& Feng, X. (2018). Reversal of reserpine-induced depression and cognitive disorder in zebrafish by sertraline and Traditional Chinese Medicine (TCM). Behavioral and Brain Functions : BBF, 14(1), 13. https://doi.org/10.1186/s12993-018-0145-8

Zhang, Y., Vanmeert, M., Siekierska, A., Ny, A., John, J., Callewaert, G., Lescrinier, E., Dehaen, W., de Witte, P. A. M., \& Kaminski, R. M. (2017). Inhibition of glutamate decarboxylase (GAD) by ethyl ketopentenoate (EKP) induces treatment-resistant epileptic seizures in zebrafish. Scientific Reports, 7(1), 7195.

https://doi.org/10.1038/s41598-017-06294-w

Zhao, Z., Li, G., Xiao, Q., Jiang, H.-R., Tchivelekete, G. M., Shu, X., \& Liu, H. (2020). Quantification of the influence of drugs on zebrafish larvae swimming kinematics and energetics. PeerJ, 8, e8374. https://doi.org/10.7717/peerj.8374

Zheng, Y.-M., Chen, B., Jiang, J.-D., \& Zhang, J.-P. (2018). Syntaxin 1B Mediates 
Berberine's Roles in Epilepsy-Like Behavior in a Pentylenetetrazole-Induced Seizure Zebrafish Model. Frontiers in Molecular Neuroscience, 11, 378.

https://doi.org/10.3389/fnmol.2018.00378

Zon, L. I., \& Peterson, R. T. (2005). In vivo drug discovery in the zebrafish. In Nature Reviews Drug Discovery (Vol. 4, Issue 1, pp. 35-44). https://doi.org/10.1038/nrd1606

\section{Supplementary data}

Table 1. Systematic review of zebrafish behaviour publications in the fields of drug testing, drug discovery, toxicology, genetics, neuroscience and other on the status and detail of reporting $\mathrm{pH}$ values of husbandry or drug treatment conditions.

\begin{tabular}{|c|c|c|c|c|}
\hline $\begin{array}{l}\text { Area } \\
\text { (Toxicology, } \\
\text { drug discovery, } \\
\text { etc.) }\end{array}$ & \begin{tabular}{|l|} 
Behavioural \\
endpoint \\
(locomotion, \\
freezing, \\
etc.) \\
\end{tabular} & $\begin{array}{l}\mathrm{pH} \\
\text { reported }\end{array}$ & $\begin{array}{l}\mathrm{pH} \text { value } \\
\text { (or range) }\end{array}$ & Reference \\
\hline Drug testing & Aggression & No & & Gutiérrez et al., 2020 \\
\hline Neuroscience & Locomotion & Yes & 8.2 & Weuring et al., 2020 \\
\hline Neuroscience & \begin{tabular}{|l|} 
Brain \\
structure \\
\end{tabular} & No & & Kedra et al., 2020 \\
\hline Drug testing & Locomotion & No & & Zhao et al., 2020 \\
\hline Toxicology & Locomotion & No & & Morbiato et al., 2020 \\
\hline Drug testing & Open Field & Yes & $7-7.5$ & Pandelides et al., 2020 \\
\hline Toxicology & Locomotion & No & & B. Wang et al., 2020 \\
\hline Drud discovery & Locomotion & No & & Sourbron et al., 2019 \\
\hline Genetics & Locomotion & No & & $\begin{array}{l}\text { Nakamachi, Tanigawa, Konno, } \\
\text { Shioda, \& Matsuda, } 2019\end{array}$ \\
\hline Neuroscience & Locomotion & No & & Pant et al., 2019 \\
\hline Genetics & Locomotion & Yes & 7.2-7.7 & $\begin{array}{l}\text { Annunziato, Jantzen, Gronske, \& } \\
\text { Cooper, } 2019\end{array}$ \\
\hline Drug discovery & Locomotion & Yes & 7.2 & Ko et al., 2019 \\
\hline Drug testing & $\begin{array}{l}\text { Locomotion, } \\
\text { Freezing }\end{array}$ & Yes & 7.2 & $\begin{array}{l}\text { Macrì, Clément, Spinello, \& Porfiri, } \\
2019\end{array}$ \\
\hline Drug testing & Locomotion & Yes & $7.2 \pm 1$ & Souders et al., 2019 \\
\hline Neuroscience & $\begin{array}{l}\text { Locomotion, } \\
\text { novel tank } \\
\text { exploration, } \\
\text { aggression, } \\
\text { predator }\end{array}$ & No & & Sarasamma et al., 2019 \\
\hline
\end{tabular}




\begin{tabular}{|c|c|c|c|c|}
\hline & $\begin{array}{l}\text { avoidance } \\
\text { test, } \\
\text { shoaling, } \\
\text { conspecific } \\
\text { social } \\
\text { interaction, } \\
\text { circadian } \\
\text { rhythm, } \\
\text { colour } \\
\text { preferences, } \\
\text { and short- } \\
\text { term } \\
\text { memory } \\
\text { tests }\end{array}$ & & & \\
\hline Drug discovery & $\begin{array}{l}\text { Locomotion, } \\
\text { Light/dark } \\
\text { preference }\end{array}$ & Yes & 9 & Chhabria et al., 2019 \\
\hline Neuroscience & Locomotion & No & & $\begin{array}{l}\text { Luchtenburg, Schaaf, \& Richardson, } \\
2019\end{array}$ \\
\hline Development & Locomotion & Yes & $8.1 \pm 0.2$ & $\begin{array}{l}\text { Fitzgerald, Kirla, Zinner, \& Vom Berg, } \\
2019\end{array}$ \\
\hline Toxicology & Locomotion & No & & Brun et al., 2019 \\
\hline Development & Locomotion & No & & Anthony N. Oliveri \& Levin, 2019 \\
\hline Neuroscience & Locomotion & No & & Chen, Tu, Schirch, Safo, \& Fu, 2019 \\
\hline Neuroscience & $\begin{array}{l}\text { Locomotion, } \\
\text { Predatory } \\
\text { response }\end{array}$ & Yes & $7.0 \pm 0.2$ & Frank et al., 2019 \\
\hline Neuroscience & Locomotion & No & & Xie et al., 2019 \\
\hline Genetics & $\begin{array}{l}\text { Light/Dark, } \\
\text { Open field, } \\
\text { Shoaling }\end{array}$ & No & & C.-X. Liu et al., 2018 \\
\hline Genetics & Locomotion & Yes & 7.4 & $\begin{array}{l}\text { Jensen, Korbut, Kania, \& Buchmann, } \\
2018\end{array}$ \\
\hline Neuroscience & $\begin{array}{l}\text { Locomotion, } \\
\text { dark flash, } \\
\text { sociability }\end{array}$ & No & & Baronio et al., 2018 \\
\hline $\begin{array}{l}\text { Neuroscience, } \\
\text { Drug testing }\end{array}$ & Locomotion & No & & S. Zhang et al., 2018 \\
\hline Air pollution & Locomotion & No & & J. S. Stevens et al., 2018 \\
\hline Neuroscience & Locomotion & No & & Crilly et al., 2018 \\
\hline Neuroscience & Locomotion & No & & Zheng, Chen, Jiang, \& Zhang, 2018 \\
\hline Neuroscience & Locomotion & No & & $\begin{array}{l}\text { Lange, Froc, Grunwald, Norton, \& } \\
\text { Bally-Cuif, } 2018\end{array}$ \\
\hline Neuroscience & Locomotion & Yes & $7.2 \pm 1$ & $\begin{array}{l}\text { Shontz, Souders, Schmidt, \& } \\
\text { Martyniuk, } 2018\end{array}$ \\
\hline Drug discovery & Locomotion & Yes & 7.3 & Bugel \& Tanguay, 2018 \\
\hline Drug discovery & Locomotion & Yes & 7.6 & Gauthier \& Vijayan, 2018 \\
\hline Neuroscience & Locomotion & Yes & 7.2 & Du et al., 2018 \\
\hline Drug testing & Locomotion & Yes & 7.2 & Lobao-Soares et al., 2018 \\
\hline
\end{tabular}




\begin{tabular}{|c|c|c|c|c|}
\hline Drug testing & Locomotion & No & & F. Li et al., 2018 \\
\hline Drug testing & $\begin{array}{l}\text { Locomotion, } \\
\text { Predatory } \\
\text { response }\end{array}$ & Yes & $7.2-7.8$ & Frank et al., 2018 \\
\hline Neuroscience & Locomotion & No & & Kopp, Legler, \& Legradi, 2018 \\
\hline Toxicology & Locomotion & No & & J. Li et al., 2018 \\
\hline Neuroscience & Locomotion & Yes & $7 \pm 0.5$ & Han, Zheng, Zhang, \& Hu, 2018 \\
\hline Toxicology & Locomotion & No & & $\begin{array}{l}\text { Anthony N Oliveri, Ortiz, \& Levin, } \\
2018 \\
\end{array}$ \\
\hline Toxicology & Locomotion & No & & Liao et al., 2018 \\
\hline Drug discovery & Locomotion & Yes & 7 & Batista et al., 2018 \\
\hline Toxicology & $\begin{array}{l}\text { Locomotion, } \\
\text { mirror biting, } \\
\text { predator } \\
\text { avoidance, } \\
\text { social } \\
\text { interaction, } \\
\text { shoaling }\end{array}$ & No & & Sarasamma et al., 2018 \\
\hline Toxicology & $\begin{array}{l}\text { Locomotion, } \\
\text { predator } \\
\text { avoidance, } \\
\text { shoaling }\end{array}$ & No & & Glazer et al., 2018 \\
\hline Toxicology & Locomotion & Yes & $7.2 \pm 0.4$ & $\begin{array}{l}\text { González, Carty, Tran, Cole, \& Lein, } \\
2018\end{array}$ \\
\hline Neuroscience & Open Field & Yes & $7.5-8$ & Grone, Qu, \& Baraban, 2017 \\
\hline Toxicology & $\begin{array}{l}\text { Locomotion, } \\
\text { exploration, } \\
\text { aggression }\end{array}$ & Yes & $6.5-7.5$ & $\begin{array}{l}\text { Bridi, Altenhofen, Gonzalez, Reolon, } \\
\text { \& Bonan, } 2017\end{array}$ \\
\hline Drug testing & Exploration & Yes & $6.5-7.5$ & Altenhofen et al., 2017 \\
\hline Neuroscience & Locomotion & Yes & 8 & (Zabinyakov et al., 2017) \\
\hline Neuroscience & Locomotion & No & & (Hu et al., 2017) \\
\hline Neuroscience & T maze & Yes & 6.8-7.1 & (Kundap et al., 2017) \\
\hline Drug discovery & Locomotion & No & & (Basnet et al., 2017) \\
\hline Neuroscience & Locomotion & No & & Knecht et al., 2017 \\
\hline Toxicology & Locomotion & Yes & 7.5 & Jia et al., 2017 \\
\hline Drug discovery & Locomotion & No & & Brock et al., 2017 \\
\hline Neuroscience & Locomotion & Yes & 7.2 & Turrini et al., 2017 \\
\hline Neuroscience & Locomotion & Yes & 6 & $\begin{array}{l}\text { Itskovits, Levine, Cohen, \& Zaslaver, } \\
2017\end{array}$ \\
\hline Drug testing & \begin{tabular}{|l|} 
Locomotion, \\
Freezing
\end{tabular} & Yes & 9 & Savoldi et al., 2017 \\
\hline Toxicology & Locomotion & Yes & 7.4 & Kao et al., 2017 \\
\hline Neuroscience & Locomotion & Yes & 7.2 & Carvan et al., 2017 \\
\hline Drug testing & Locomotion & No & & Misztal et al., 2017 \\
\hline Neuroscience & Locomotion & Yes & $6.8-7.5$ & Y. Zhang et al., 2017 \\
\hline Neuroscience & Locomotion & No & & Y. Liu et al., 2017 \\
\hline Drug discovery & Locomotion & No & & Palmér et al., 2017 \\
\hline Neuroscience & Locomotion & No & & Ek et al., 2016 \\
\hline
\end{tabular}




\begin{tabular}{|c|c|c|c|c|}
\hline Drug discovery & Locomotion & Yes & 7.2 & Sun et al., 2016 \\
\hline Drug testing & Locomotion & No & & Wilson et al., 2016 \\
\hline Genetics & $\begin{array}{l}\text { Open Field, } \\
\text { aggression }\end{array}$ & Yes & 7.2-7.7 & Jantzen, Annunziato, \& Cooper, 2016 \\
\hline Neuroscience & Locomotion & Yes & 7.5 & $\begin{array}{l}\text { Sterling, Chang, Karatayev, Chang, \& } \\
\text { Leibowitz, } 2016\end{array}$ \\
\hline Toxicology & Locomotion & Yes & 7.2-7.7 & $\begin{array}{l}\text { Jantzen, Annunziato, Bugel, \& } \\
\text { Cooper, } 2016\end{array}$ \\
\hline Toxicology & Locomotion & Yes & $6.8-7.5$ & Pham et al., 2016 \\
\hline Toxicology & Locomotion & Yes & 7 & Kristofco et al., 2016 \\
\hline Toxicology & Locomotion & Yes & $7-7.6$ & Xiaowei He et al., 2016 \\
\hline Neuroscience & \begin{tabular}{|l|} 
Thigmotaxis, \\
Scototaxis \\
\end{tabular} & No & & $\begin{array}{l}\text { Baiamonte, Parker, Vinson, \& } \\
\text { Brennan, } 2016\end{array}$ \\
\hline Toxicology & \begin{tabular}{|l|}
$\begin{array}{l}\text { Locomotion, } \\
\text { shoaling }\end{array}$ \\
\end{tabular} & No & & Glazer, Hahn, \& Aluru, 2016 \\
\hline Drug Testing & \begin{tabular}{|l|} 
Locomotion. \\
Thigmotaxis \\
\end{tabular} & No & & X. Liu et al., 2016 \\
\hline Toxicology & Locomotion & No & & Sternberg et al., 2016 \\
\hline Neuroscience & $\begin{array}{l}\text { Locomotion, } \\
\text { exploration, } \\
\text { predator } \\
\text { avoidance }\end{array}$ & No & & Bailey et al., 2016 \\
\hline Neuroscience & Locomotion & No & & Benedetti et al., 2016 \\
\hline Toxicology & Locomotion & Yes & 7.2 & $\begin{array}{l}\text { Mora-Zamorano, Svoboda, \& Carvan } \\
2016\end{array}$ \\
\hline Neuroscience & Locomotion & No & & $\begin{array}{l}\text { Gonzalez, Remick, Creton, \& Colwill, } \\
2016\end{array}$ \\
\hline Neuroscience & Locomotion & No & & Kasica et al., 2016 \\
\hline Neuroscience & Locomotion & Yes & 7.2 & Braga et al., 2016 \\
\hline Neuroscience & Light/Dark & No & & X. Li et al., 2015 \\
\hline Drug testing & $\begin{array}{l}\text { Locomotion, } \\
\text { anxiety, } \\
\text { exploration }\end{array}$ & No & & $\begin{array}{l}\text { Sterling, Karatayev, Chang, Algava, \& } \\
\text { Leibowitz, } 2015\end{array}$ \\
\hline Neuroscience & Locomotion & No & & Seebacher, Little, \& James, 2015 \\
\hline Drug testing & Locomotion & No & & $\begin{array}{l}\text { Jarema, Hunter, Shaffer, Behl, \& } \\
\text { Padilla, } 2015\end{array}$ \\
\hline Drug Testing & Locomotion & Yes & $6.8-7.2$ & $\begin{array}{l}\text { Nowicki, Tran, Chatterjee, \& Gerlai, } \\
2015\end{array}$ \\
\hline Neuroscience & Exploration & No & & Facchin, Duboué, \& Halpern, 2015 \\
\hline Genetics & Locomotion & No & & Radev et al., 2015 \\
\hline Drug discovery & Locomotion & Yes & 7 & Y. Wang et al., 2015 \\
\hline Neuroscience & \begin{tabular}{|l|} 
Exploration, \\
sociability \\
\end{tabular} & No & & $\begin{array}{l}\text { Bortolotto, de Melo, Cognato, } \\
\text { Vianna, \& Bonan, } 2015 \\
\end{array}$ \\
\hline Drug testing & \begin{tabular}{|l|} 
Exploration, \\
sociability, \\
predatory \\
response \\
\end{tabular} & No & & A N Oliveri, Bailey, \& Levin, 2015 \\
\hline Drug testing & Stress test & No & & Baiamonte, Brennan, \& Vinson, 2015 \\
\hline
\end{tabular}




\begin{tabular}{|c|c|c|c|c|}
\hline Neuroscience & $\begin{array}{l}\text { Locomotion, } \\
\text { shoaling }\end{array}$ & No & & $\begin{array}{l}\text { Dubey, Ganeshpurkar, Bansal, \& } \\
\text { Dubey, } 2015\end{array}$ \\
\hline Neuroscience & \begin{tabular}{|l}
$\begin{array}{l}\text { Locomotion, } \\
\text { anxiety }\end{array}$ \\
\end{tabular} & No & & Vignet et al., 2015 \\
\hline Drug discovery & Locomotion & No & & $\begin{array}{l}\text { Holcombe, Schalomon, \& Hamilton, } \\
2014\end{array}$ \\
\hline Neuroscience & Locomotion & No & & Makhija \& Jagtap, 2014 \\
\hline Neuroscience & Locomotion & Yes & 7 & $\begin{array}{l}\text { Zada, Tovin, Lerer-Goldshtein, } \\
\text { Vatine, \& Appelbaum, } 2014\end{array}$ \\
\hline Neuroscience & Locomotion & Yes & 7-7.5 & Long et al., 2014 \\
\hline Neuroscience & Locomotion & No & & $\begin{array}{l}\text { Fernandes, Tran, Abraham, \& Gerlai, } \\
2014\end{array}$ \\
\hline Neuroscience & Locomotion & No & & Woods et al., 2014 \\
\hline Neuroscience & $\begin{array}{l}\text { Locomotion, } \\
\text { thigmotaxis }\end{array}$ & Yes & $7-7.2$ & X. Li et al., 2014 \\
\hline Neuroscience & Locomotion & No & & Ward et al., 2014 \\
\hline Neuroscience & Locomotion & No & & Knogler \& Drapeau, 2014 \\
\hline Neuroscience & Locomotion & No & & $\begin{array}{l}\text { Menelaou, Udvadia, Tanguay, \& } \\
\text { Svoboda, } 2014\end{array}$ \\
\hline Neuroscience & Locomotion & No & & $\begin{array}{l}\text { Knogler, Ryan, Saint-Amant, \& } \\
\text { Drapeau, } 2014\end{array}$ \\
\hline Drug testing & Locomotion & No & & $\begin{array}{l}\text { Puttonen, Sundvik, Rozov, Chen, \& } \\
\text { Panula, } 2013\end{array}$ \\
\hline Toxicology & Locomotion & Yes & 7.4 & Duan et al., 2013 \\
\hline Neuroscience & \begin{tabular}{|l|} 
Locomotion \\
\end{tabular} & No & & Kyzar et al., 2013 \\
\hline Neuroscience & Locomotion & No & & $\begin{array}{l}\text { Irons, Kelly, Hunter, Macphail, \& } \\
\text { Padilla, } 2013\end{array}$ \\
\hline Neuroscience & \begin{tabular}{|l|}
$\begin{array}{l}\text { Locomotion, } \\
\text { shoaling }\end{array}$ \\
\end{tabular} & No & & Maaswinkel, Zhu, \& Weng, 2013 \\
\hline Neuroscience & Locomotion & No & & Ikeda et al., 2013 \\
\hline Neuroscience & Locomotion & Yes & 7.6 & Afrikanova et al., 2013 \\
\hline Drug testing & Locomotion & No & & Tran \& Gerlai, 2013 \\
\hline Neuroscience & \begin{tabular}{|l|} 
Shoaling, \\
thigmotaxis \\
\end{tabular} & No & & $\begin{array}{l}\text { Maaswinkel, Le, He, Zhu, \& Weng, } \\
2013\end{array}$ \\
\hline Neuroscience & Locomotion & No & & $\begin{array}{l}\text { Mirat, Sternberg, Severi, \& Wyart, } \\
2013\end{array}$ \\
\hline Neuroscience & Locomotion & Yes & 7 & $\begin{array}{l}\text { Baldissarelli, Capiotti, Bogo, Ghisleni, } \\
\text { \& Bonan, } 2012\end{array}$ \\
\hline $\begin{array}{l}\text { Genetics, drug } \\
\text { testing }\end{array}$ & Locomotion & No & & $\begin{array}{l}\text { Shimada, Hirano, Nishimura, \& } \\
\text { Tanaka, } 2012\end{array}$ \\
\hline Environmental & Locomotion & No & & \\
\hline Neuroscience & Locomotion & Yes & $5.8-7.8$ & Xiong He, Zhong, \& Che, 2012 \\
\hline Neuroscience & Locomotion & No & & Formella et al., 2012 \\
\hline Neuroscience & Locomotion & No & & Saili et al., 2012 \\
\hline Toxicology & Locomotion & No & & Pruvot et al., 2012 \\
\hline Neuroscience & Escape & No & & Mu, Li, Zhang, \& Du, 2012 \\
\hline Neuroscience & Locomotion & No & & $\begin{array}{l}\text { Lambert, Bonkowsky, \& Masino, } \\
2012\end{array}$ \\
\hline
\end{tabular}




\begin{tabular}{|c|c|c|c|c|}
\hline Drug testing & Locomotion & No & & $\begin{array}{l}\text { Truong, Saili, Miller, Hutchison, \& } \\
\text { Tanguay, } 2012\end{array}$ \\
\hline Drug testing & $\begin{array}{l}\text { Locomotion, } \\
\text { shoaling }\end{array}$ & Yes & 7.2 & Gebauer et al., 2011 \\
\hline Drug testing & Locomotion & No & & $\begin{array}{l}\text { Klee, Ebbert, Schneider, Hurt, \& } \\
\text { Ekker, } 2011 \\
\end{array}$ \\
\hline Neuroscience & Locomotion & No & & Cachat et al., 2011 \\
\hline Neuroscience & Light/Dark & Yes & 7 & $\begin{array}{l}\text { Maximino, Lima, Olivera, Picanço- } \\
\text { Diniz, \& Herculano, } 2011 \\
\end{array}$ \\
\hline Neuroscience & Locomotion & No & & Kyriakatos et al., 2011 \\
\hline Neuroscience & Scototaxis & Yes & 7 & $\begin{array}{l}\text { Maximino, da Silva, Gouveia, \& } \\
\text { Herculano, } 2011\end{array}$ \\
\hline Neuroscience & Locomotion & Yes & 8 & $\begin{array}{l}\text { Int J Comp Psychol. 2010;23(1):82- } \\
90 .\end{array}$ \\
\hline Drug discovery & Locomotion & No & & Rihel et al., 2010 \\
\hline Neuroscience & Locomotion & No & & Knogler, Liao, \& Drapeau, 2010 \\
\hline Neuroscience & Locomotion & No & & Egan et al., 2009 \\
\hline Neuroscience & Locomotion & No & & V Sallinen et al., 2009 \\
\hline Neuroscience & Locomotion & No & & Ville Sallinen et al., 2009 \\
\hline Genetics & Locomotion & No & & $\begin{array}{l}\text { Pietri, Manalo, Ryan, Saint-Amant, \& } \\
\text { Washbourne, } 2009 \\
\end{array}$ \\
\hline Drug testing & Locomotion & No & & Peng et al., 2009 \\
\hline Drug discovery & Locomotion & No & & $\begin{array}{l}\text { Barros, Alderton, Reynolds, Roach, \& } \\
\text { Berghmans, } 2008\end{array}$ \\
\hline Neuroscience & $\begin{array}{l}\text { Locomotion, } \\
\text { thigmotaxis }\end{array}$ & No & & Bencan \& Levin, 2008 \\
\hline Neuroscience & Locomotion & No & & Thirumalai \& Cline, 2008 \\
\hline Neuroscience & Locomotion & No & & $\begin{array}{l}\text { McLean, Masino, Koh, Lindquist, \& } \\
\text { Fetcho, } 2008\end{array}$ \\
\hline Neuroscience & Locomotion & No & & Boehmler et al., 2007 \\
\hline Neuroscience & Locomotion & No & & Baraban et al., 2007 \\
\hline Neuroscience & Locomotion & No & & McDearmid \& Drapeau, 2006 \\
\hline Genetics & Locomotion & No & & Cui et al., 2005 \\
\hline Neuroscience & Locomotion & No & & Brustein \& Drapeau, 2005 \\
\hline Neuroscience & Locomotion & No & & $\begin{array}{l}\text { Anichtchik, Kaslin, Peitsaro, Scheinin, } \\
\text { \& Panula, } 2004\end{array}$ \\
\hline Neuroscience & Locomotion & No & & Saint-Amant \& Drapeau, 2000 \\
\hline
\end{tabular}

